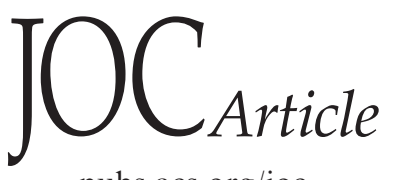

pubs.acs.org/joc

\title{
$N$-Aryl Pyrrolo-tetrathiafulvalene Based Ligands: Synthesis and Metal Coordination
}

\author{
Jean-Yves Balandier, Marcos Chas, Paul I. Dron, Sébastien Goeb, David Canevet, \\ Ahmed Belyasmine, Magali Allain, and Marc Sallé* \\ Institut des Sciences et Technologies Moléculaires d'Angers, MOLTECH ANJOU, UMR CNRS 6200, \\ Université d'Angers, 2 Bd Lavoisier, 49045 Angers Cedex, France \\ marc.salle@univ-angers.fr
}

Received December 3, 2009

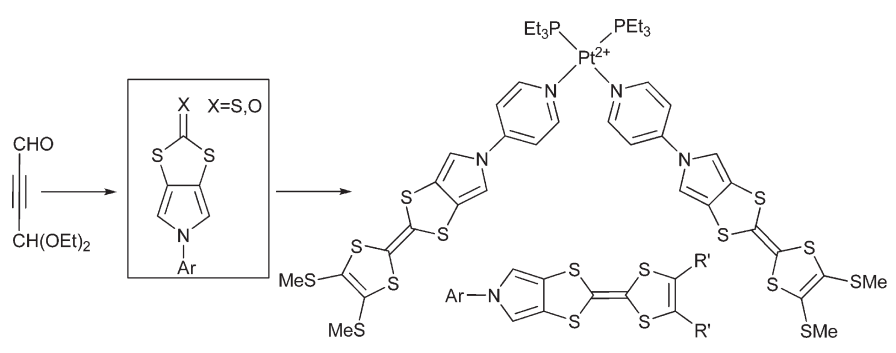

A straightforward general synthetic access to $N$-aryl-1,3-dithiolo[4,5-c]pyrrole-2-thione derivatives 6 from acetylenedicarbaldehyde monoacetal is depicted. In addition to their potentiality as precursors to dithioalkyl-pyrrole derivatives, thiones $\mathbf{6}$ are key building blocks to $N$-aryl monopyrrolotetrathiafulvalene (MPTTF) derivatives 10. X-ray structures of four of these thiones intermediates, reminiscent of the corresponding MPTTF derivatives, are provided. When the aryl group is a binding pyridyl unit, the MPTTF derivative 10a can coordinate $\mathrm{M}(\mathrm{II})$ salts $(\mathrm{M}=\mathrm{Pt}, \mathrm{Pd})$. The first examples of metal-directed orthogonal MPTTF-based dimers 11-14, obtained through coordination of 10a to cis-blocked square planar Pt or Pd complexes are described. Studies on the parameters influencing the dimer construction are presented, as well as first recognition properties of the resulting electronrich clip for $\mathrm{C}_{60}$.

\section{Introduction}

Tetrathiafulvalene (TTF) and its derivatives have been the subject of intense interest for nearly four decades. The initial observation of remarkable conducting metallic behavior for some of the corresponding salts ${ }^{1}$ has continuously stimulated very active research regarding transport properties of this $\pi$-electron-donating molecule in the solid state. ${ }^{2}$ Moreover, due to their electron-donating properties and the possibility of reversible stepwise oxidation forming stable radical cation and dication species, tetrathiafulvalene derivatives have found use as redox switches in a myriad of recent molecular and supramolecular architectures that we recently

(1) (a) Wudl, F.; Wobschall, D.; Hufnagel, E. J. J. Am. Chem. Soc. 1972, 94, 670-672. (b) Ferraris, J.; Cowan, D. O.; Walatka, V., Jr; Perlstein, J. H. J. Am. Chem. Soc. 1973, 95, 948-949. (c) Coleman, L. B.; Cohen, M. J.; Sandman, D. J.; Yamagishi, F. G.; Garito, A. F.; Heeger, A. J. Solid State Commun. 1973, 12, 1125-1132.

(2) For recent reviews on this topic, see special issue on molecular conductors : Batail, P., Guest Editor. Chem. Rev. 2004, 11.

(3) For a recent review, see: Canevet, D.; Sallé, M.; Zhang, G.; Zhang, D.; Zhu, D. Chem. Commun. 2009, 2245-2269. reviewed. ${ }^{3}$ Interest for this $\pi$-electron donor results from a conjunction of remarkable electronic properties and a versatile chemistry, allowing functionalization for a broad range of applications. ${ }^{2,3}$ For instance, efforts have been produced for linking binding units to the redox-active TTF moiety, in order to (i) prepare TTF-based redox-switchable receptors able to electrochemically detect a metal cation guest $^{3}$ and (ii) obtain hybrid organic-inorganic materials endowed with rich solid-state physical properties. ${ }^{4}$ In those two cases, several examples of TTF-based systems involving a binding pyridyl unit have been described. ${ }^{3,4}$ A significant breakthrough in the use of TTF-based systems comes from the synthesis some years ago of the more extended monopyrrolo- and bispyrrolo-tetrathiafulvalene derivatives (MPTTF and BPTTF, respectively, Scheme 1). ${ }^{5,6}$ These

(4) For a recent review, see: Lorcy, D.; Bellec, N.; Fourmigué, M.; Avarvari, N. Coord. Chem. Rev. 2009, 253, 1398-1438.

(5) Jeppesen, J. O.; Becher, J. Eur. J. Org. Chem. 2003, 17, 3245-3266.

(6) (a) Jeppesen, J. O.; Takimiya, K.; Jensen, F.; Brimert, T.; Nielsen, K.; Thorup, N.; Becher, J. J. Org. Chem. 2000, 65, 5794-5805. (b) Balandier, J.-Y.; Belyasmine, A.; Sallé, M. Synthesis 2006, 17, 2815-2817. 


\section{SCHEME 1}

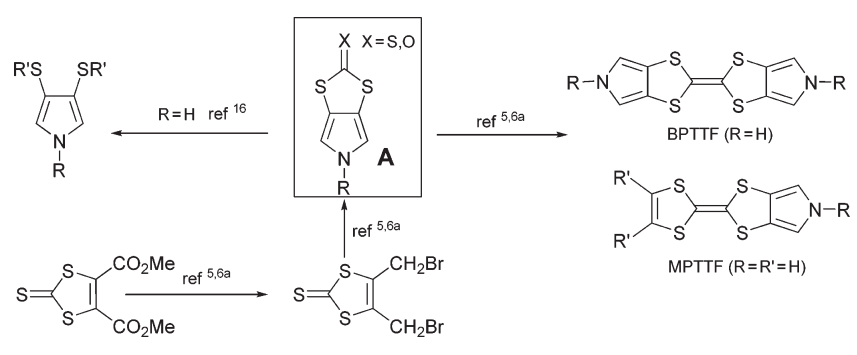

systems have been extensively incorporated in a great variety of molecular and supramolecular architectures. ${ }^{5,7}$ Nevertheless, in comparison to the parent TTF unit, the study of their synthetic versatility has been less developed. In particular, only few examples of MPTTF or BPTTF derivatives incorporating binding units have been described. ${ }^{5,8}$ In the course of our studies, related to metal-directed self-assembly of electron-rich polygons, ${ }^{9}$ we have been interested in introducing aromatic binding units (such as 4-pyridyl or 4-cyano phenyl groups) at the periphery of the pyrroloTTF framework, which to the best of our knowledge has not been described yet. Beyond these units, there is a need for a general synthetic route to $N$-aryl pyrroloTTF precursors. We propose here a new general access to $N$-aryl-1,3-dithiolo[4,5c]pyrrole-2-thione derivatives, key building blocks to $N$-aryl MPTTF and BPTTF derivatives, and we develop their application in the first examples of metal-directed orthogonal MPTTF-based dimers, through their coordination to cisblocked square planar Pt or Pd complexes.

\section{Results and Discussion}

A synthetic access to key intermediates $\mathbf{A}$ has already been described (with $\mathrm{R}=\mathrm{Ts}$, Scheme 1), through a route involving the synthesis of 4,5-bis(bromomethyl)-1,3-dithiole-2thione and subsequent annelation with tosylamide. ${ }^{6 a}$

Noteworthy, only few examples of $N$-arylated derivatives of $\mathbf{A}$ are described. They are obtained by modifying the above-described strategy, through reaction of an aromatic amine $/ \mathrm{K}_{2} \mathrm{CO}_{3}{ }^{10,11}$ (instead of tosylamide) along the cyclization step with 4,5-bis(bromomethyl)-1,3-dithiole-2-thione. Nevertheless, such strategy cannot be applied in the case of insertion of a pyridyl group, because of undesired reactivity

(7) See for instance: (a) Nielsen, K. A.; Cho, W. S.; Jeppesen, J. O.; Lynch, V. M.; Becher, J.; Sessler, J. L. J. Am. Chem. Soc. 2004, 126, 1629616297. (b) Nielsen, K. A.; Cho, W. S.; Sarova, G. H.; Petersen, B. M.; Bond, A. D.; Becher, J.; Jensen, F.; Guldi, D. M.; Sessler, J. L.; Jeppesen, J. O. Angew. Chem., Int. Ed. 2006, 45, 6848-6853.

(8) Trippé, G.; Levillain, E.; Le Derf, F.; Gorgues, A.; Sallé, M.; Jeppesen, J. O.; Nielsen, K.; Becher, J. Org. Lett. 2002, 4, 2461-2464.

(9) Balandier, J.-Y.; Chas, M.; Goeb, S.; Dron, P. I.; Rondeau, D.; Belyasmine, A.; Gallego, N.; Sallé, M. Submitted for publication.

(10) Nygaard, S.; Leung, K. C. F.; Aprahamian, I.; Ikeda, T.; Saha, S.; Laursen, B. W.; Kim, S. Y.; Hansen, S. W.; Stein, P. C.; Flood, A. H.; Stoddart, J. F.; Jeppesen, J. O. J. Am. Chem. Soc. 2007, 129, 960-970.

(11) Bingzhu, Y.; Yonghua, Y.; Zhiqi, C.; Kimiaki, I. Heterocycles 2004, 63,1577

(12) Though we could efficiently ( $>65 \%$ yield) operate a model $N$-arylation of the naked pyrrole heterocycle to produce $N$-p-pyridyl pyrrole, by reaction of 4-chloropyridine with pyrryl potassium or by copper-catalysed coupling of pyrrole with 4-iodopyridine, all of our attempts to direct $N$-arylation of $\mathbf{A}(\mathrm{R}=\mathrm{H})$ according to the same procedures failed. Also, an example of $N$-arylation on a preformed MPTTF, using the Buchwald copper catalyst system, has been described but failed in our attempts to introduce the pyridyl unit: Li, H.; Lambert, C. Chem.-Eur. J. 2006, 12, $1144-1155$. between 4-amino pyridine and the bromomethyl electrophilic group. We have therefore developed a new access to $N$-aryl (including $N$-pyridyl) 1,3-dithiolo[4,5-c]pyrrole-2thione A. ${ }^{12}$

The synthesis of thiones $\mathbf{6} \mathbf{a}-\mathbf{f}$ is described in Scheme 2. The starting key compound is the commercially available mono(diethyl)acetal of acetylene dicarbaldehyde $\mathbf{1}^{13}$ This electrophilic alkyne cycloadds onto ethylenetrithiocarbonate to produce 1,3-dithiol-2-thione derivative $2 .{ }^{14}$ Imine 3 a could be obtained by condensation of $\mathbf{2}$ with 4-aminopyridine/piperidine in presence of molecular sieves or $\mathrm{P}_{2} \mathrm{O}_{5}$ in refluxing toluene, which invariably results in low yields $(<18 \%)$. The most efficient route involves instead an azaWittig reaction between 2 and iminophosphorane $4 ;^{15}$ in this case, imino derivative intermediate $\mathbf{3 a}$ is not isolated and is directly reduced with sodium borohydride to produce amino-acetal 5a in $70 \%$ yield from $\mathbf{2}$. The key point in this strategy corresponds to synthesis of final thione 6a, obtained in $79 \%$ yield through a single reaction, by treatment of 5a with Amberlyst A15. Actually, this reaction corresponds to three successive chemical steps: acetal deprotection, intramolecular cyclization, and deshydration.

The generalization of this method to other aromatic $N$-arylated 1,3-dithiolo[4,5-c]pyrrole-2-thiones $\mathbf{6 b}-\mathbf{f}$ was operated using various aromatic amines that are condensed with aldehyde 2 (Scheme 2 and Table 1). The general route involves the preparation of imine derivatives $\mathbf{3}$, reduction with $\mathrm{NaBH}_{4}$, and then treatment with Amberlyst A15. Because of the instability of some intermediate compounds, the sequence from $\mathbf{2}$ to $\mathbf{6}$ is followed without isolation of imines 3 (except $\mathbf{3 b}$ ) or amine intermediates $\mathbf{5}$.

Conversion of 1,3-dithiolo[4,5-c]pyrrole-2-thione $\mathbf{A}(\mathrm{X}=$ $\mathrm{S})$ to the corresponding dithiocarbonate $(\mathrm{X}=\mathrm{O})$ provides an efficient entry to dithioalkyl pyrrole derivatives, as shown recently ${ }^{16}$ in the case of $\mathrm{R}=\mathrm{H}$ (Scheme 1). Accordingly, we converted thioxo compounds $\mathbf{6 a}$ and $\mathbf{6 b}$ to their oxo derivatives $\mathbf{6}^{\prime} \mathbf{a}$ and $\mathbf{6}^{\prime} \mathbf{b}$, respectively, by treatment with mercuric acetate in glacial acetic acid. Yields were remarkably low $\left(\mathbf{6}^{\prime} \mathbf{a}, 10 \% ; \mathbf{6}^{\prime} \mathbf{b}, 54 \%\right)$, which we assign to a competitive binding of $\mathrm{Hg}(\mathrm{II})$ by the pyridyl moiety along the reaction. We therefore modified the procedure, by operating the transchalcogenation step prior to introduction of the pyridyl substituent (Scheme 3 ). Oxo derivative $\mathbf{2}^{\prime}$ was quantitatively produced in this case. ${ }^{14} \mathrm{~A}$ similar synthetic path as for the preparation of $\mathbf{6 a}$ was then followed for the preparation of $\mathbf{6}^{\prime} \mathbf{a}$ (imine formation, reduction, intramolecular cyclization with aromatization).

In order to further extend the linear extension of the corresponding BPTTF derivative, a Sonogashira coupling was carried out between thione $6 \mathbf{e}$ and 4-pyridyl acetylene 7, prepared in two steps from 4-bromopyridine, ${ }^{17}$ to produce thione 8 in $45 \%$ yield (Scheme 4 ).

(13) Gorgues, A.; Stephan, D.; Belyasmine, A.; Khanous, A.; Le Coq, A. Tetrahedron 1990, 46, 2817.

(14) Sallé, M.; Gorgues, A.; Jubault, M.; Boubekeur, K.; Batail, P. Tetrahedron 1992, 48, 3081-3090.

(15) Balandier, J.-Y.; Belyasmine, A.; Sallé, M. Eur. J. Org. Chem. 2008, 269-276.

(16) (a) Li, H.; Lambert, C. J. Mater. Chem. 2005, 15, 1235. (b) Li, H.; Lambert, C.; Stahl, R. Macromolecules 2006, 39, 2049-2055.

(17) Yu, L.; Lindsey, J. S. J. Org. Chem. 2001, 66, 7402. 


\section{SCHEME 2}

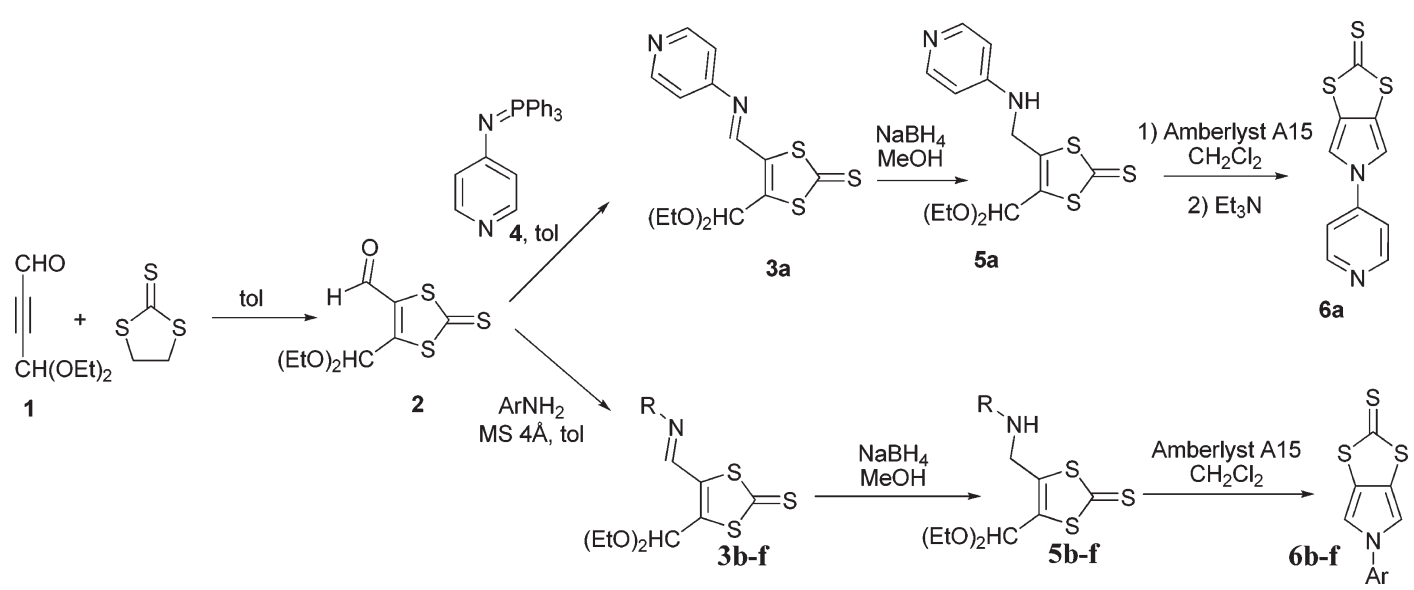

\section{SCHEME 3}

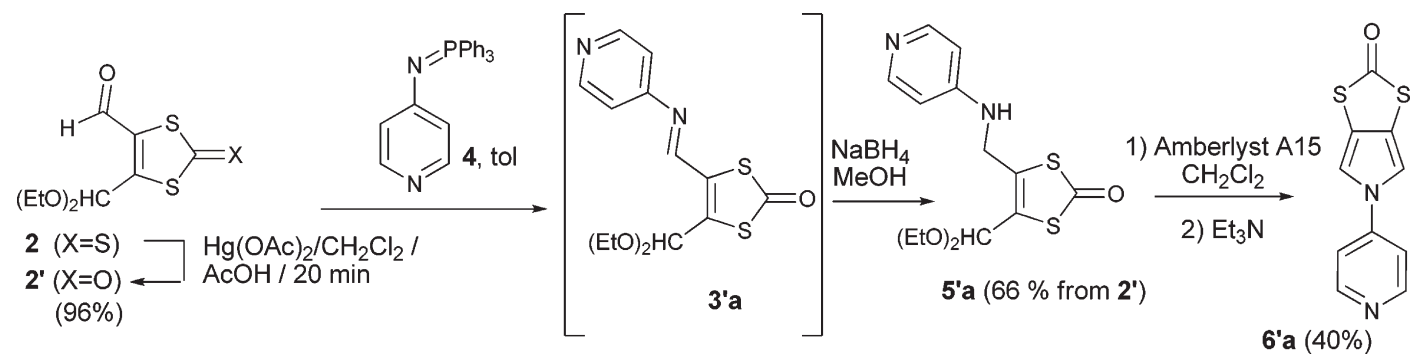

TABLE 1. Synthesis of Thiones $6 \mathbf{a}-\mathbf{e}$ from $\mathbf{2}$ and Various Aryl Amines Aryl amine Thione $\mathbf{6} \quad$ Global yield from $\mathbf{2}^{a}$

b

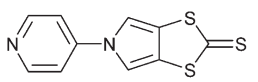

55

6a
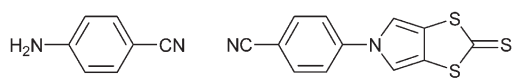

6b
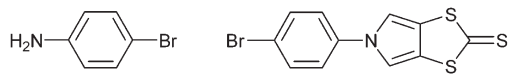

6c
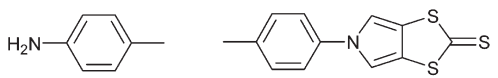

6d
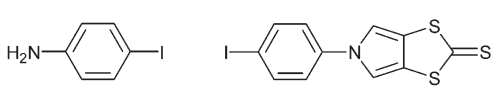

6e

34

${ }^{a}$ Isolated product. ${ }^{b}$ Aza-Wittig reaction from 4.

An evident interest of thiones intermediates $\mathbf{6 a}, \mathbf{b}$, relies on the preparation of new MPTTF and BPTTF derivatives $N$-substituted with coordinating units. Monotopic MPTTF derivatives could be reached through a cross-coupling reaction between thiones $\mathbf{6}^{\prime} \mathbf{a}$ (or $\mathbf{6}^{\prime} \mathbf{b}$ ) and 1,3-dithiole-2-thione $\mathbf{9}$ in refluxing trimethylphosphite (Scheme 5) to afford 10a (respectively $\mathbf{1 0 b}$ ).

Thiones $\mathbf{5 a}$ and $\mathbf{6} \mathbf{a}-\mathbf{c}$ could be grown as single crystals, and corresponding X-ray structures were solved by X-ray diffraction. Crystallographic data are gathered in Table SI-1 in Supporting Information, and corresponding molecular structures are shown in Figure 1.

Thione 5a crystallizes as yellow needles in the monoclinic space group $P 2_{1} / n$. Mean planes of both heterocycles of $5 \mathbf{a}$ are nearly perpendicular $\left(82.55(5)^{\circ}\right)$, which of course is not the case for thiones $\mathbf{6 a}-\mathbf{c}$. $N$-Substituted 1,3-dithiolo[4,5-c]pyrrole-2-thiones $\mathbf{6 a}-\mathbf{c}$ present molecular structures whose basic fragments prefigure the structure of the corresponding MPTTF or BPTTF derivatives. Some structural distinctions can be found between thiones $6 \mathbf{a}-\mathbf{c}$, in particular the rotation angle around the $\mathrm{N}_{\text {(pyrrole) }}-\mathrm{C}_{(\text {Ar) }}$ bond, between both aromatic rings. In the case of $\mathbf{6 b}$, mean planes defined by $\left(\mathrm{N}_{01} \mathrm{C}_{05} \mathrm{C}_{02} \mathrm{~S}_{02} \mathrm{C}_{01} \mathrm{~S}_{03} \mathrm{C}_{03} \mathrm{C}_{04}\right)$ and $\left(\mathrm{C}_{06} \mathrm{C}_{07} \mathrm{C}_{08} \mathrm{C}_{09} \mathrm{C}_{10} \mathrm{C}_{11}\right)$ deviate by only $8.17(8)^{\circ}$. The corresponding rotation angle around the $\mathrm{N}_{(\text {pyrrole) }}-\mathrm{C}_{(\mathrm{Ar})}$ bond reaches a value of $33.1(1)^{\circ}$ and $39.0(1)^{\circ}$ for $\mathbf{6 a}$ and $\mathbf{6 c}$, respectively.

DFT calculations (Gaussian 2003, (Becke3LYP $\left(\right.$ B3LYP)) ${ }^{18}$ have been carried out on $\mathbf{1 0 a}, \mathbf{b}$. These calculations were led with atomic bases 6-31G(d,p) on all atoms. Frontier orbitals of TTF derivatives 10a,b are shown in Table 2. For both of them, the electronic density in the HOMO is located on the central donating skeleton and on the lateral pyrrole motifs, illustrating the strong $\pi$-delocalization in BPTTF derivatives

(18) Becke, D. J. Chem. Phys. 1993, 98, 5648. 

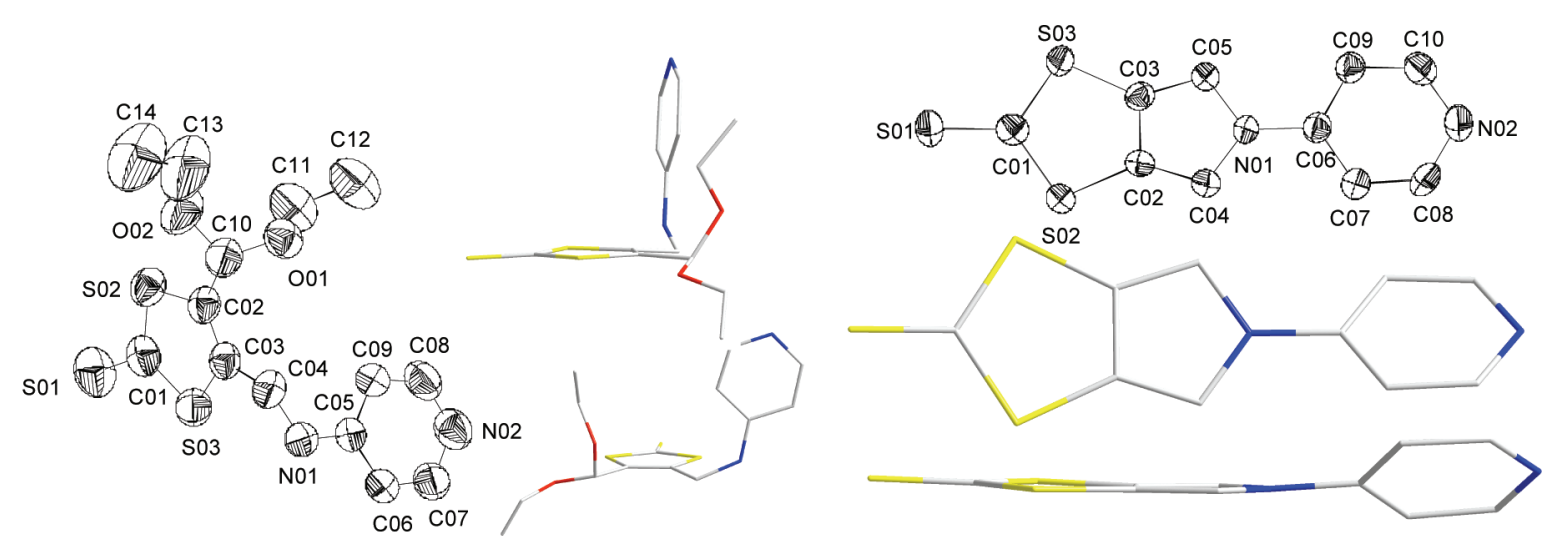

a)

b)
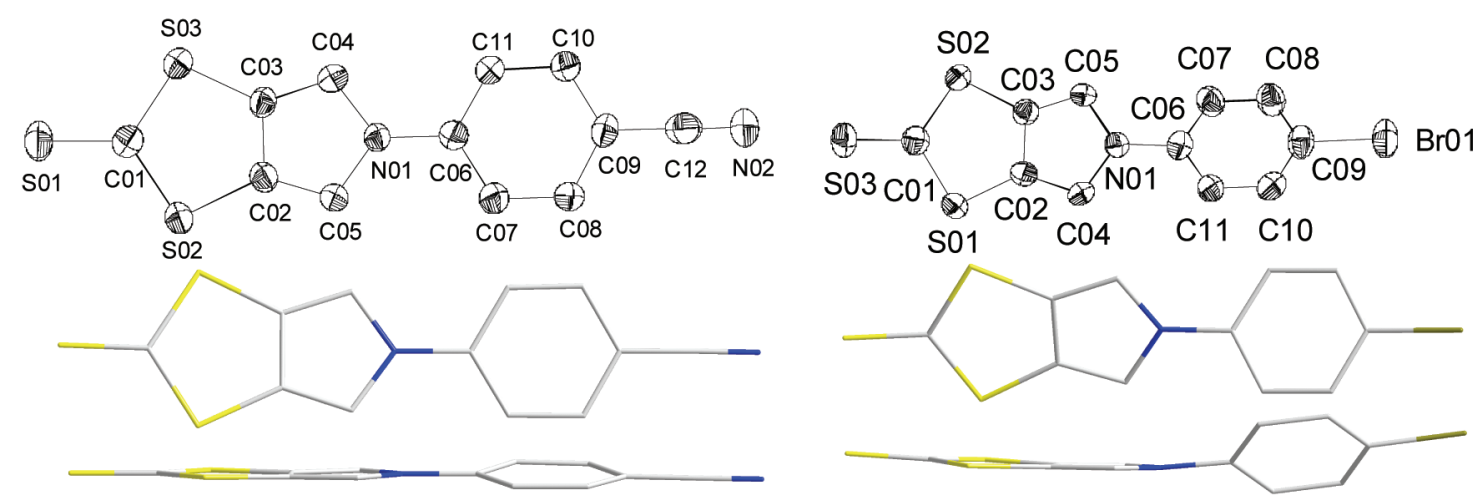

c)

d)

FIGURE 1. X-ray structures of 1,3-dithiol-2-thione 5a (a) and 1,3-dithiolo[4,5-c]pyrrole-2-thiones 6a (b), $6 \mathbf{b}$ (c), and $\mathbf{6 c}$ (d) (H atoms omitted).

SCHEME 4

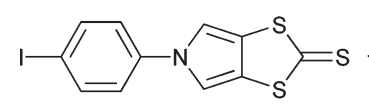

$6 e$

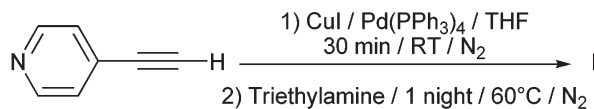

7
2) Triethylamine $/ 1$ night $/ 60^{\circ} \mathrm{C} / \mathrm{N}_{2}$

$45 \%$

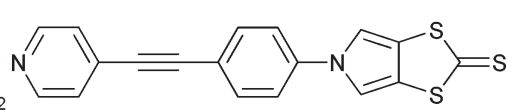

8

\section{SCHEME 5}

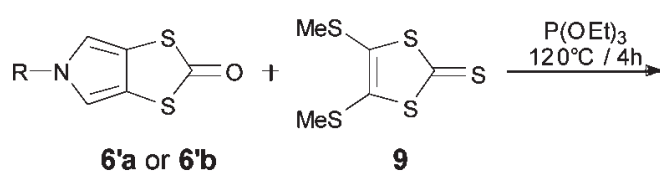

6 'a or 6 'b

compared to the parent TTF framework. ${ }^{5}$ On the other hand, the LUMO is essentially distributed on pyrrole and pyridyl heterocycles (10a) or $p$-cyanophenyl units (10b). The corresponding energies are very similar to that of unsubstituted BPTTF, anticipating a comparable high $\pi$-donating ability.

These rigid monotopic ligands are suitable candidates for construction of metalla-assembled structures of controlled geometries, by association with chosen metal complexes. cis-Blocked square planar $\mathrm{Pt}(\mathrm{II})$ or $\mathrm{Pd}(\mathrm{II})$ salts (such as $d p p p \mathrm{M}(\mathrm{OTf})_{2}$ or $e n \mathrm{M}\left(\mathrm{NO}_{3}\right)_{2}$ with $\mathrm{M}=\mathrm{Pt}$ or $\mathrm{Pd}$ ) present two orthogonal positions for binding ligands, typically pyridine derivatives. Based on such metaldirected assembly, various exotic supramolecular structures (e.g., polygons and polyhedron) have been reached in a straightforward way, ${ }^{19}$ architectures that are otherwise very challenging to synthesize using classical covalent chemistry. 
TABLE 2. HOMO and LUMO of MPTTF Derivatives 10a,b

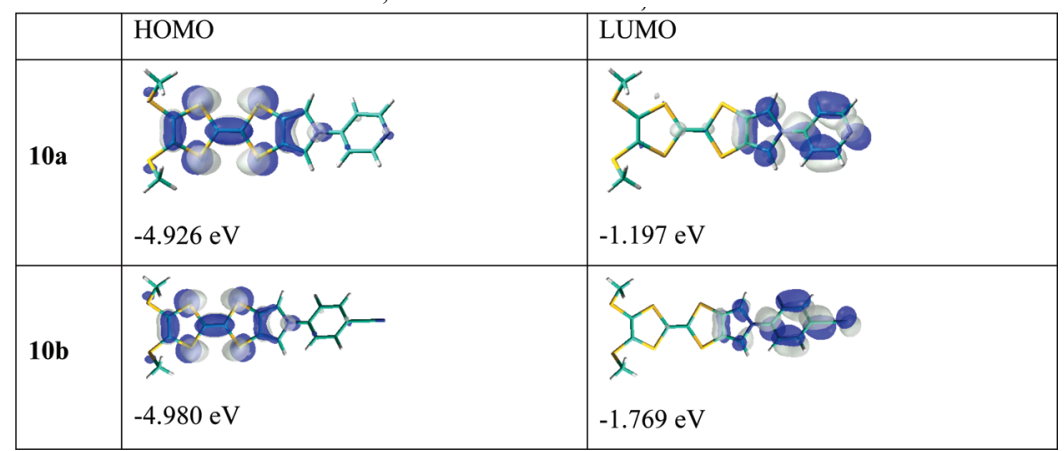

\section{SCHEME 6}

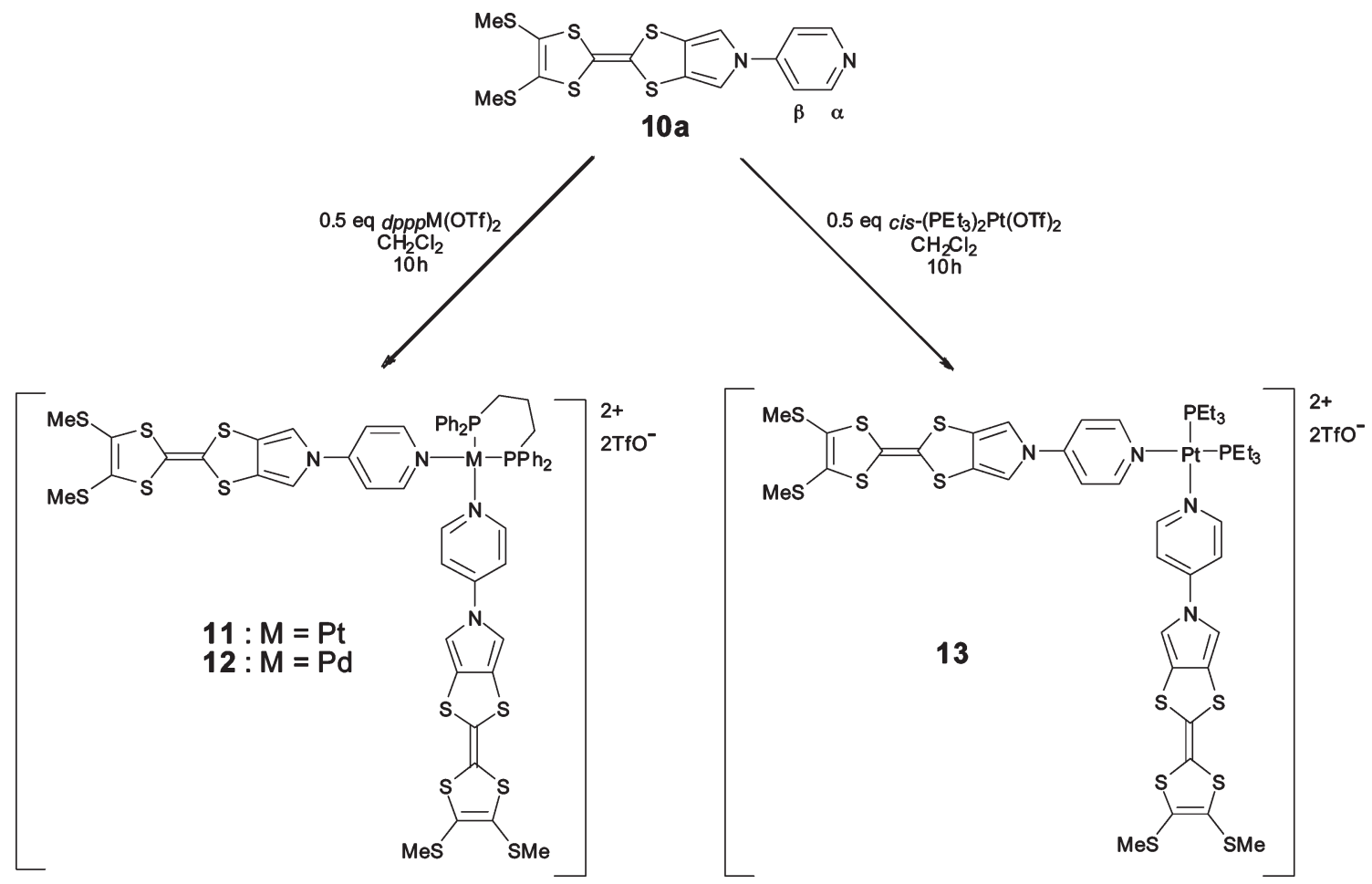

On this ground, a metal-assembled dimer presenting two orthogonal MPTTF-based ligands and one metal corner constitutes therefore a base elemental unit regarding their correponding self-assembled polyhedra and may provide useful information on their self-assembly process. In addition, such angular TTF dimers correspond to a class of derivatives that have been the focus of a continuous interest, for two reasons: (i) electrical conducting properties of TTFbased organic salts often suffer from their anisotropic organization in the crystal; among the solutions proposed to increase their dimensionality, important efforts have been

(19) For recent reviews, see: (a) Li, S. S.; Northrop, B. H.; Yuan, Q. H.; Wan, L. J.; Stang, P. J. Acc. Chem. Res. 2009, 42, 249. (b) Stang, P. J. J. Org. Chem. 2009, 74, 2. (c) Northrop, B. H.; Chercka, D.; Stang, P. J. Tetrahedron 2008, 64, 11495. (d) Northrop, B. H.; Yang, H. B.; Stang, P. J. Chem. Commun. 2008, 5896. (e) Zangrando, E.; Casanova, M.; Alessio, E. Chem. Rev. 2008, 108, 4979. (f) Fujita, M.; Tominaga, M.; Hori, A.; Therrien, B. Acc. Chem. Res. 2005, 38, 369. (g) Fiedler, D.; Leung, D. H.; Bergman, R. G.; Raymond, K. N. Acc. Chem. Res. 2005, 38, 349. (h) Kaiser, A.; Bauerle, P. Top. Curr. Chem. 2005, 127. (i) Würthner, F.; You, C. C.; Saha-Möller, C. R. Chem. Soc. Rev. 2004, 33, 133. developed by synthetic chemists to design two or threedimensionnal architectures, including orthogonal TTF dimers; ${ }^{20,21}$ (ii) such orthogonal dimers can be assimilated to electron-rich clips that potentially present a good affinity for electron-poor units. For instance, these interactions have been recently used to bind $\mathrm{C}_{60}$ within a clip involving two $\pi$-donating extended TTF units. $^{22}$

Dimers 11, 12, and 13 (Scheme 6) were prepared through reaction between bis(triflate) complexes $\operatorname{dppp} \mathrm{M}(\mathrm{OTf})_{2}(\mathrm{M}=\mathrm{Pd}$,

(20) (a) Gómez, R.; Segura, J. L.; Martín, N. J. Org. Chem. 2000, 65, 7566. (b) Tatemitsu, H.; Nishikawa, E.; Sakata, H.; Misumi, S. Synth. Met. 1987, 19, 565. (c) Ueda, K.; Yamanoha, M.; Sugimoto, T.; Fujita, H.; Ugawa, A.; Yakushi, K.; Kano, K. Chem. Lett. 1997, 461.

(21) An example of a TTF dimer involving a conformationnally flexible TTF-based unit and $\operatorname{dppp} \mathrm{M}(\mathrm{OTf})_{2}(\mathrm{M}=\mathrm{Pt}, \mathrm{Pd})$ has recently been described: Devic, T.; Avarvari, N.; Batail, P. Chem.-Eur. J. 2004, $10,3697$.

(22) (a) Pérez, E. M.; Sierra, M.; Sánchez, L.; Torres, M. R; Viruela, R.; Viruela, P. M.; Ortí, E.; Martín, N. Angew. Chem., Int. Ed. 2007, 46, 1847. (b) Pérez, E. M.; Sánchez, L.; Fernandez, G.; Martín, N. J. Am. Chem. Soc. 2006, 128,7172 . 
TABLE 3. Chemical Shifts $\left(\mathrm{CD}_{2} \mathrm{Cl}_{2}\right)$ for Complexes 11-13 and Corresponding Starting Complexes ${ }^{a}$

\begin{tabular}{|c|c|c|c|c|}
\hline \multirow[b]{2}{*}{ complex } & \multirow[b]{2}{*}{${ }^{31} \mathrm{P}$ NMR $\delta(\mathrm{ppm})$} & \multirow[b]{2}{*}{${ }^{19} \mathrm{~F}$ NMR $\delta(\mathrm{ppm})$} & \multicolumn{2}{|c|}{${ }^{1} \mathrm{H}$ NMR $\delta(\mathrm{ppm})$} \\
\hline & & & $\mathrm{H}_{\alpha}$ & $\mathrm{H}_{\beta}$ \\
\hline$\overline{d p p p \operatorname{Pt}(\mathrm{OTf})_{2}}$ & -9.8 & -79.3 & & \\
\hline 11 & -14.7 & -79 & 8.87 & 6.87 \\
\hline$d p p p \mathrm{Pd}(\mathrm{OTf})_{2}$ & 17.7 & 79.2 & & \\
\hline 12 & 6.8 & -79 & 8.83 & 6.85 \\
\hline$c i s-\left(\mathrm{PEt}_{3}\right)_{2} \mathrm{Pt}(\mathrm{OTf})_{2}$ & 9.4 & -79.4 & & \\
\hline 13 & -2.5 & -79 & 9.10 & 7.40 \\
\hline
\end{tabular}
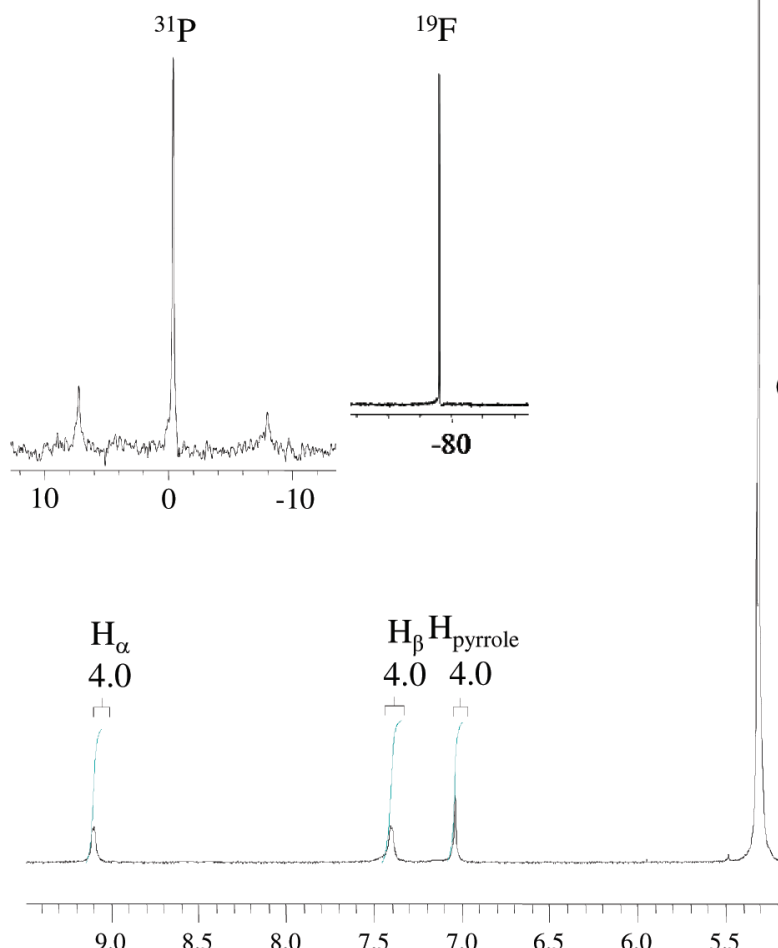

FIGURE 2. ${ }^{1} \mathrm{H},{ }^{31} \mathrm{P}$, and ${ }^{19} \mathrm{~F}$ NMR spectra of $13\left(5 \times 10^{-3} \mathrm{~mol} \mathrm{~L}^{-1}\right)$ in $\mathrm{CD}_{2} \mathrm{Cl}_{2}$.

$\mathrm{Pt}$ ) (or cis-( $\left.\left.\mathrm{PEt}_{3}\right)_{2} \mathrm{Pt}(\mathrm{OTf})_{2}\right)$ with an excess of $\mathbf{1 0 a}$ in dichloromethane at $\mathrm{rt}(>80 \%$ yields).

Complexes 11-13 have been characterized by multinuclear NMR $\left({ }^{1} \mathrm{H},{ }^{31} \mathrm{P},{ }^{19} \mathrm{~F}\right)$ analyses in $\mathrm{CD}_{2} \mathrm{Cl}_{2}$. Chemical shifts are gathered in Table 3, and NMR spectra of $\mathbf{1 3}$ (illustrative example) are shown in Figure 2 (see also Figures SI-1 and SI2 in Supporting Information for 11 and 12). As expected for symmetrical structures, only a simple set of signals is detected in the ${ }^{1} \mathrm{H}$ NMR spectra; in particular three signals are observed for protons of the pyridine $\left(\mathrm{H}_{\alpha}\right.$ and $\left.\mathrm{H}_{\beta}\right)$ and the pyrrole moieties. $\mathrm{H}_{\alpha}$ and more particularly $\mathrm{H}_{\beta}$ appear significantly upfield shifted in $\mathbf{1 3}$ related to $d p p p$ complexes $\mathbf{1 1}$ and $12 ;{ }^{23}$ this difference is ascribed to the shielding effect provided by the $d p p p$ phenyl groups that sit over the pyridine

(23) Ligand 10a, being insoluble in $\mathrm{CD}_{2} \mathrm{Cl}_{2}$, no direct comparison has been possible between the free ligand and the corresponding complexes.

(24) Stang, P. J.; Cao, D. H.; Saito, S.; Arif, A. M. J. Am. Chem. Soc. $1995,117,6273$. moiety. ${ }^{24}$ Only one signal is observed in the ${ }^{31} \mathrm{P}$ NMR spectra, accompanied in the case of $\mathbf{1 1}$ and $\mathbf{1 3}$ by Pt satellite peaks from the spin-spin ${ }^{195} \mathrm{Pt}-{ }^{31} \mathrm{P}$ coupling. Signals in $\mathbf{1 1}$ and 12 are shifted by ca. 5 and 11 ppm, respectively, related to corresponding starting metallic salts $\left(\operatorname{dppp} \mathrm{M}(\mathrm{OTf})_{2}(\mathrm{M}=\right.$ $\mathrm{Pd}, \mathrm{Pt})$ ), whereas the shift reaches $12 \mathrm{ppm}$ for 13. These values are comparable with those described for self-assembled systems based on 4,4'-bipyridyle ligands and the same metal(II) triflates. ${ }^{25}$ The ${ }^{19} \mathrm{~F}$ NMR exhibits a single signal at $-79 \mathrm{ppm}$ in all cases, which associated to vibration bands at 1160 and $1130 \mathrm{~cm}^{-1}$ in the IR spectrum, are usual values for triflate counterion. ${ }^{26}$

Ligand 10a can also react with en $\mathrm{Pd}\left(\mathrm{NO}_{3}\right)_{2}$ in DMSO- $d_{6}$, to generate complex 14 (Scheme 7). Only $15 \mathrm{~min}$ are required in this case. This complex shows a good solubility in DMSO,

(25) Stang, P. J.; Cao, D. H. J. Am. Chem. Soc. 1994, 116, 4981.

(26) Lawrence, G. A. Chem. Rev. 1986, 86, 17. 


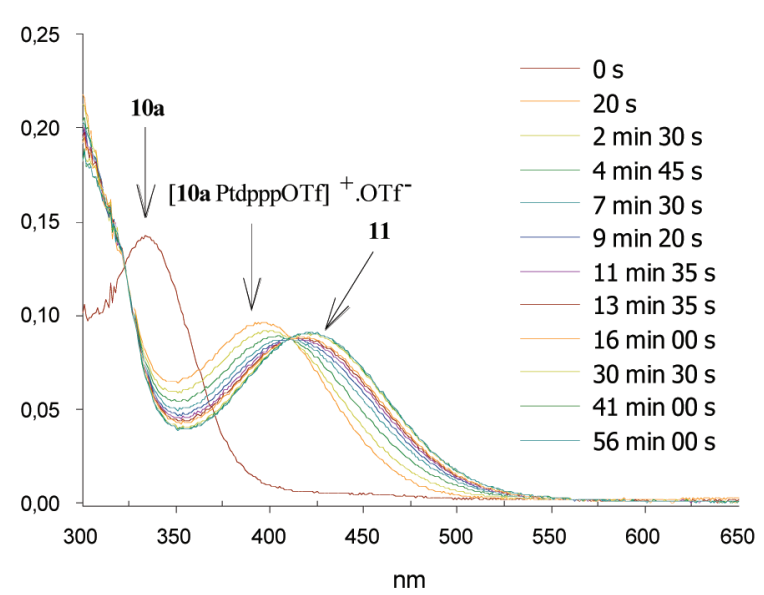

a)

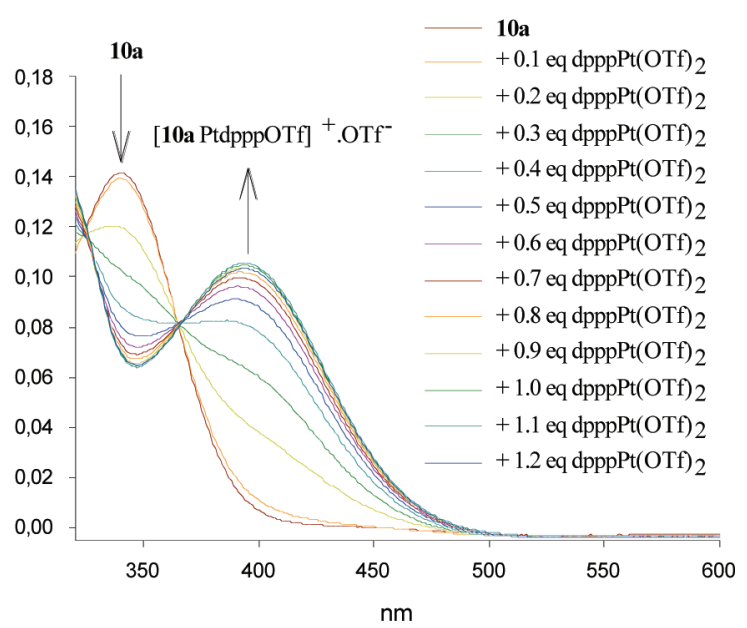

b)

FIGURE 3. (a) Stepwise formation of $\mathbf{1 1}$ monitored by UV-vis spectroscopy (mixture of $\mathbf{1 0 a}\left(5 \times 10^{-5} \mathrm{~mol} \mathrm{~L}^{-1}\right)$ in $\mathrm{CH}_{3} \mathrm{CN}_{\text {with }} 0.5$ equiv of $\left.d p p p \operatorname{Pt}(\mathrm{OTf})_{2}\right)$. (b) Formation of the monosubstituted complex (mixture of $\mathbf{1 0 a}\left(5 \times 10^{-5} \mathrm{~mol} \mathrm{~L}^{-1}\right)$ in $\mathrm{CH}_{3} \mathrm{CN}$ with $d p p p \mathrm{Pt}(\mathrm{OTf})_{2}(0-1.2$ equiv)).

\section{SCHEME 7}

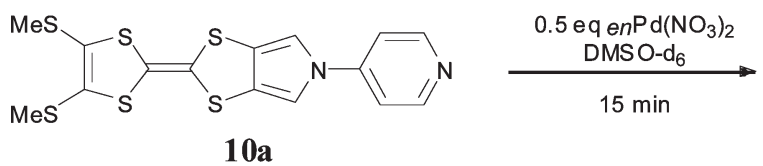

and formation of $\mathbf{1 4}$ can be monitored by NMR (DMSO- $\left.d_{6}\right)$ (Figure SI-3 and Table SI-2 in Supporting Information). Pyridine protons are significantly shifted in $\mathbf{1 4}\left(\mathrm{H}_{\alpha}=8.68\right.$ ppm ; $\left.\mathrm{H}_{\beta}=7.79 \mathrm{ppm}\right)$ relatively to free ligand 10a $\left(\mathrm{H}_{\alpha}=\right.$ $\left.8.56 \mathrm{ppm} ; \mathrm{H}_{\beta}=7.46 \mathrm{ppm}\right)$. On the contrary, it is worth noting that after heating en $\mathrm{Pt}\left(\mathrm{NO}_{3}\right)_{2}$ with an excess of $10 \mathbf{a}$ at $100{ }^{\circ} \mathrm{C}$ in DMSO- $d_{6}$ for 3 days, only a mixture of mono- and disubstituted complexes could be obtained.

$\mathrm{UV}$-vis spectroscopy has been used to probe the formation of complexes 11-13. Two cases can be identified. Direct formation of the Pd complex $\mathbf{1 2}$ is observed upon addition of 0.5 equiv of $d p p p \mathrm{Pd}(\mathrm{OTf})_{2}$ to 10a (Figure SI-4 in Supporting Information). The absorption band at $\lambda_{\max }=334 \mathrm{~nm}$ corresponding to free ligand $\mathbf{1 0 a}$ decreases progressively to the benefit of a new one at $421 \mathrm{~nm}$ corresponding to complex 12. A different behavior is observed upon formation of the Pt analogue 11 (Figure 3). Addition of 0.5 equiv of $d p p p$ Pt$(\mathrm{OTf})_{2}$ to ligand $\mathbf{1 0 a}$ is accompanied by decrease of the band at $334 \mathrm{~nm}$ and the concomitent progressive appearance of a new one at $397 \mathrm{~nm}$. This band is attributed to the

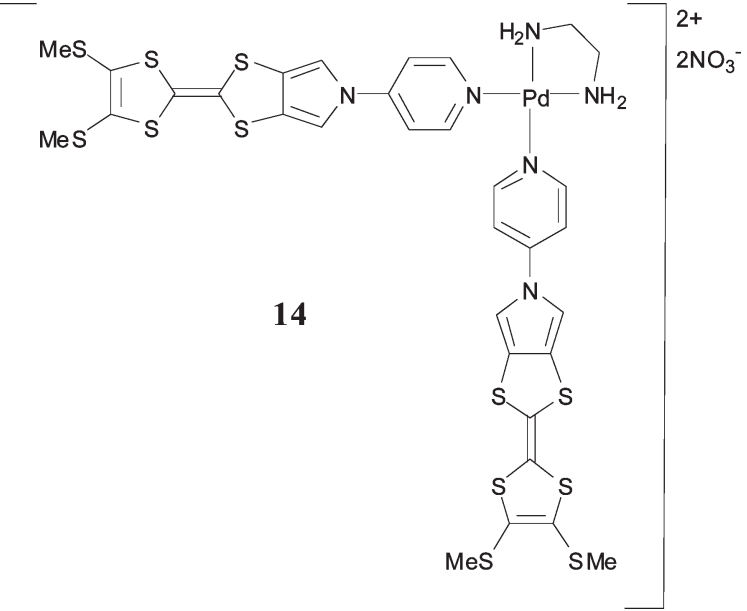

displacement of only one triflate by a pyridine ligand on the metal center. This band progressively red-shifts with time to a new value at $421 \mathrm{~nm}$ (Figure 3a), assigned to complex 11. An isosbestic point at $412 \mathrm{~nm}$ illustrates existence of only two species in equilibrium in the solution, i.e., the monosubstituted complex $(397 \mathrm{~nm})$ and the target dimer $11(421 \mathrm{~nm})$. This assignement is confirmed by an additional experiment: when quick addition of $d p p p \operatorname{Pt}(\mathrm{OTf})_{2}(0-1.2$ equiv) is carried out on a solution of $\mathbf{1 0 a}$, only one band appears, at 397 $\mathrm{nm}$, which does not evolve anymore for more than 1 equiv introduced, confirming the 1:1 stoichiometry (Figure 3b). Therefore, whereas no intermediate could be observed at $\mathrm{rt}$ upon formation of the Pd complex 12, the monosubstituted intermediate could be observed for the Pt analogue 11. This difference is directly correlated to the more energetically demanding $\mathrm{Pt}-\mathrm{N}$ bond related to the more labile $\mathrm{Pd}-\mathrm{N}$ one.

In the case of the cis- $\left(\mathrm{PEt}_{3}\right)_{2} \mathrm{Pt}(\mathrm{OTf})_{2}$, we observe the rapid formation of the bis substituted complex 13 at $423 \mathrm{~nm}$ (Figure SI-5 in Supporting Information); in addition, no evolution of the spectrum is observed for more than 0.5 equiv 

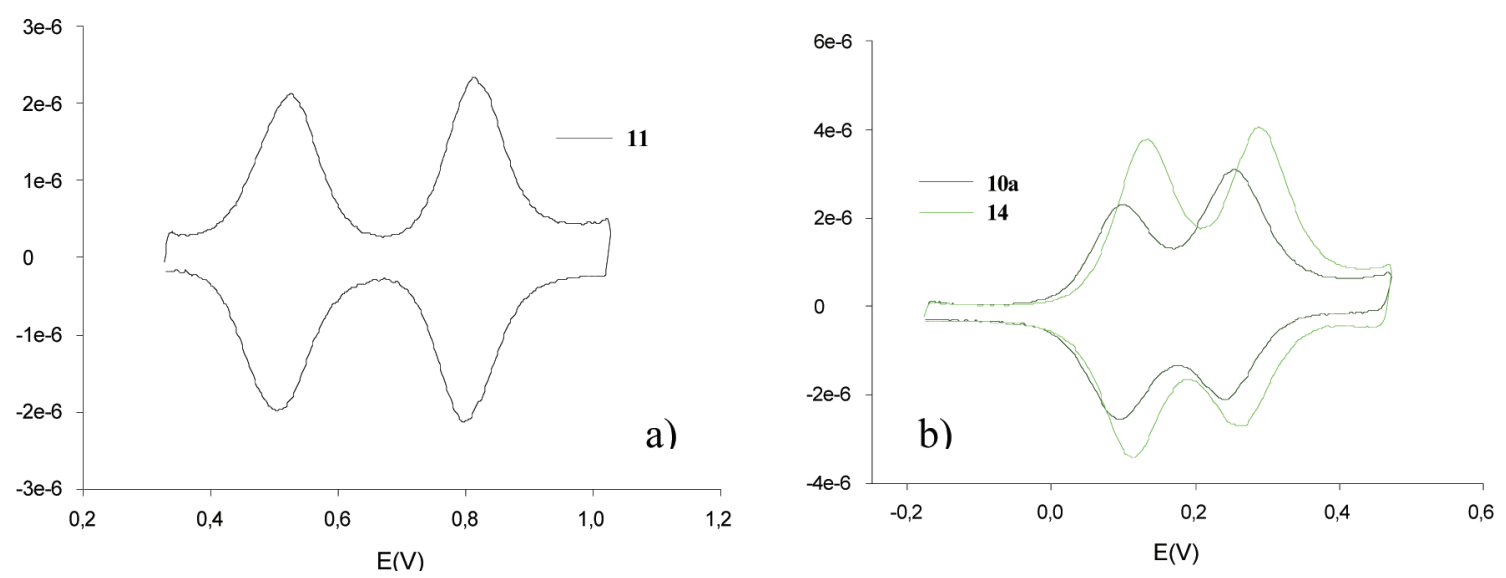

FIGURE 4. Deconvoluted $\mathrm{CV}$ of (a) $11\left(5 \times 10^{-4} \mathrm{~mol} \mathrm{~L}^{-1}\right) ; \mathrm{NBu}_{4} \mathrm{PF}_{6}\left(10^{-1} \mathrm{~mol} \mathrm{~L}^{-1}\right), v=100 \mathrm{mV} \mathrm{s}{ }^{-1}, v s \mathrm{AgCl} / \mathrm{Ag}, \mathrm{CH}_{3} \mathrm{CN} / \mathrm{CH}_{2} \mathrm{Cl}{ }_{2}(1 / 1), \mathrm{Pt}$; (b) $10 \mathrm{a}\left(2.5 \times 10^{-4} \mathrm{~mol} \mathrm{~L}^{-1}\right)$ and $14\left(4.5 \times 10^{-4} \mathrm{~mol} \mathrm{~L}^{-1}\right), \mathrm{NBu}_{4} \mathrm{PF}_{6}\left(10^{-1} \mathrm{~mol} \mathrm{~L}^{-1}\right), v=100 \mathrm{mV} \mathrm{s}{ }^{-1}, \mathrm{DMF}, \mathrm{Pt}, \mathrm{Fc} / \mathrm{Fc}^{+}=478 \mathrm{mV}$.

of $c i s-\left(\mathrm{PEt}_{3}\right)_{2} \mathrm{Pt}(\mathrm{OTf})_{2}$ (Figure SI-6 in Supporting Information), which confirms the rapid formation of the 2:1 (10a/Pt) complex.

We could not characterize any complex formation using the $p$-cyanophenyl MPTTF derivative $\mathbf{1 0 b}$. No reaction occurs with $d p p p \operatorname{Pd}(\mathrm{OTf})_{2}$, whereas the solution instantaneously turns green upon addition of $\mathrm{Pt}(\mathrm{II})$ complexes $\left(\right.$ dppp $\left.\mathrm{Pt}(\mathrm{OTf})_{2}, c i s-\left(\mathrm{PEt}_{3}\right) \mathrm{Pt}(\mathrm{OTf})_{2}\right)$, a color that is characteristic of MPTTF oxidation. This is confirmed by a UV-vis titration study, for which very similar spectra are observed upon a progressive treatment of $\mathbf{1 0 b}$ with cis- $\left(\mathrm{PEt}_{3}\right)_{2} \mathrm{Pt}(\mathrm{OTf})_{2}$ or with the $\mathrm{NOSbF}_{6}$ oxidizing agent (Figure SI-7 in Supporting Information).

It has been shown that metalla-assembled structures involving $\operatorname{dppp} \mathrm{M}(\mathrm{OTf})_{2}(\mathrm{M}=\mathrm{Pt}, \mathrm{Pd})$ are stable in a large window of potentials. ${ }^{27,28}$ The three complexes 11-13 present analogous cyclic voltammograms, which are characterized by occurrence of two well-defined reversible redox systems (Figure 4a, Figure SI-8 and Table SI-3 in Supporting Information). For each complex, no appearance of any interaction between both electroactive units can be observed from the deconvoluted $\mathrm{CV}$. The two redox systems are well resolved, indicating that both redox units are electrochemically independent.

Coulometric measurements have been performed on $\mathbf{1 3}$ by thin layer cyclic voltammetry (TLCV), with ferrocene as internal redox reference (Figure SI-9 in Supporting Information). This technique has shown its efficiency for determining coulometric data with TTF derivatives. ${ }^{29}$ Contrary to conventional cyclic voltammetry, in TLCV the current is not limited by the kinetics of mass transfer to the electrode, and all of the material confined within the thin layer is involved in the electrode reaction. Compound $\mathbf{1 3}$ shows the expected well-defined two redox waves, indicating that both MPTTF units behave independently. Importantly, comparison of both MPTTF redox waves area with the one of ferrocene used as an internal redox reference shows that two electrons are exchanged at each redox processes. Therefore, the first and second redox waves correspond to two simultaneous

(27) Würthner, F.; Sautter, A.; Schmid, D.; Weber, P. J. A. Chem.-Eur. J. 2001, 7, 894 .

(28) You, C. C.; Würthner, F. J. Am. Chem. Soc. 2003, 125, 9716.

(29) Carlier, R.; Frère, P.; Sallé, M.; Roncali, J.; Jubault, M.; Tallec, A.; Gorgues, A. Adv. Mater. 1993, 5, 445. one-electron oxidations of the two (MeS) ${ }_{2}$ MPTTF into a bis(cation-radical) and a bis(dication) successively. In the case of 14, the CV could be run in DMF, a solvent in which ligand 10a is also soluble. Deconvoluted voltammograms of the free ligand and the complex are superimposed in Figure $4 \mathrm{~b}$. In both cases, two reversible redox waves are observed as expected (Table SI-4 in Supporting Information). Similarity of both CV shapes illustrates the lack of any detectable electrochemical interactions between MPTTF units in the complex. A positive shift of $E_{\mathrm{ox}}^{1}$ and $E_{\mathrm{ox}}^{2}$ by $+35 \mathrm{mV}$ is observed for the complex compared to the free ligand, accounting for a more difficult oxidation of the redox unit once it is bound to the metal center. This behavior is well-known in the field of redox-responsive ligands and has been extensively illustrated with various types of TTF-based ligands designed for electrochemical detection of cations. ${ }^{3}$ The fact that a positive shift is also observed for $E_{\mathrm{ox}}^{2}$ is an indication that the metal is still bound at this potential, ${ }^{30}$ confirming the robustness of the complex and its ability to generate an electrochemically stable hexacationic species.

Taking advantage of the robustness of the complexes, we probed their ability to act as $\mathrm{C}_{60}$ receptors since electron-rich receptors, such as those based on TTF derivatives, appear attractive and several recent works depict complexation of electron-poor fullerene by molecular architectures incorporating two or more electron-rich TTF analogues. ${ }^{22,31}$ In particular, Martín et al. have described the synthesis of a tweezer incorporating two large extended-TTF units, which shows a good affinity for $\mathrm{C}_{60}\left(K=\mathrm{ca} .3 \times 10^{3} \mathrm{~mol} \mathrm{~L}^{-1}\right.$ in chlorobenzene). ${ }^{22 b}$

The binding affinity of $\mathbf{1 3}$ for $\mathrm{C}_{60}$ was studied by UV-visible titration. Increasing amounts of $\mathrm{C}_{60}$ were added to a solution of $\mathbf{1 3}$ in dichloromethane (Figure 5).

(30) (a) Dolder, S.; Liu, S. X.; Le Derf, F.; Sallé, M.; Neels, A; Decurtins, S. Org. Lett. 2007, 9, 3753-3756. (b) Balandier, J.-Y.; Belyasmine, A.; Sallé, M. Eur. J. Org. Chem. 2008, 269. (c) Benhaoua, C.; Mazari, M.; Mercier, N.; Le Derf, F.; Sallé, M. New J. Chem. 2008, 32, 913-916.

(31) (a) Nielsen, K. A.; Cho, W. S.; Sarova, G. H.; Petersen, B. M.; Bond, A. D.; Becher, J.; Jensen, F.; Guldi, D. M.; Sessler, J. L.; Jeppesen, J. O. Angew. Chem., Int. Ed. 2006, 45, 6848-6853. (b) Nielsen, K. A.; MartínGomis, L.; Sarova, G. H.; Sanguinet, L.; Gross, D. E.; Fernandez-Lazaro, F.; Stein, P. C.; Levillain, E.; Sessler, J. L.; Guldi, D. M.; Sastre-Santos, A.; Jeppesen, J. O. Tetrahedron 2008, 64, 8449-8463. (c) Fernández, G.; Pérez, E. M.; Sánchez, L.; Martín, N. Angew. Chem., Int. Ed. 2008, 47, 1094-1097. (d) Pérez, E. M.; Martín, N. Chem. Soc. Rev. 2008, 37, 1512-1519. 


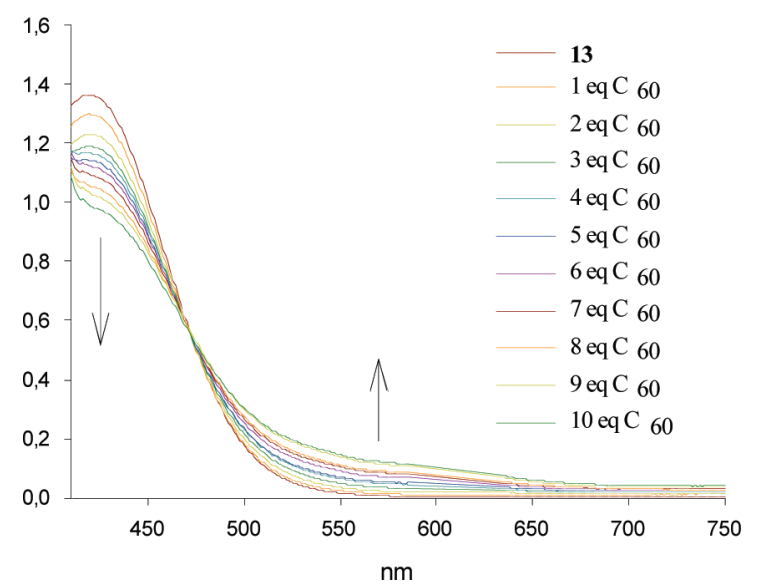

FIGURE 5. (a) $\mathrm{UV}$-vis titration of $13\left(5 \times 10^{-5} \mathrm{~mol} \mathrm{~L}^{-1}, \mathrm{CH}_{2} \mathrm{Cl}_{2}\right)$ with $\mathrm{C}_{60}\left(5 \times 10^{-3} \mathrm{~mol} \mathrm{~L}^{-1}, \mathrm{CS}_{2}\right)$.

Upon addition of $\mathrm{C}_{60}$, a decrease of the absorption band at $421 \mathrm{~nm}$ corresponding to $\mathbf{1 3}$ is observed and is accompanied by a progressive increase of a new band at $575 \mathrm{~nm}$ assigned to complex 13- $\mathrm{C}_{60}$. An isosbestic point at $475 \mathrm{~nm}$ indicates the existence of two species in equilibrium in the solution, i.e., free ligand 13 and complex $13-\mathrm{C}_{60}$. From the BenesiHildebrand curve (Figure SI-10 in Supporting Information), a 1:1 stoichiometry is found and an association constant of $\log K=3.15$ is determined. At this stage, it is worth noting that, though incorporating donor units devoid of any concave fragments and presenting a smaller $\pi$-extension than exTTF analogues, ${ }^{22 b}$ compound $\mathbf{1 3}$ exhibits a good affinity for the spherical electron-poor $\mathrm{C}_{60}$. Such result partially diverges from recent observations made with a tweezer incorporating two parent TTF units (instead of MPTTF in 13), for which a poor affinity was found for $\mathrm{C}_{60}{ }^{32}$ Therefore, beside a favorable spatial distribution of the two orthogonal electron-rich moieties that compensates for the lack of conformational flexibility within the tweezer, additional recognition elements must be considered in $\mathbf{1 3}$ compared to the TTF analogue. ${ }^{32}$ They presumably result from a combination of (i) a greater $\pi$-extension involving heteroaromatic rings of the MPTTF moieties and (ii) the presence of a metal ion whose effect cannot be excluded, since it is known to potentially have a strong influence on the binding ability of the receptor, as demonstrated for instance with porphyrinbased tweezers. ${ }^{33}$ To address this point, work is in due course for designing new MPTTF-based tweezers devoid of any assembling metal ion.

\section{Conclusion}

A new general synthetic strategy to $N$-aryl-substituted MPTTF derivatives is presented, including the case of introduction of a metal-binding pyridyl group. Coordination ability of the corresponding ligand is shown with cis-blocked $\mathrm{Pd}(\mathrm{II})$ and $\mathrm{Pt}(\mathrm{II})$ salts, giving rise to the first examples of self-assembled rigid and orthogonal electron-rich MPTTF

(32) Pérez, E. M.; Capodilupo, A. L.; Fernández, G.; Sánchez, L.; Viruela, P. M.; Viruela, R.; Ortí, E.; Bietti, M.; Martín, N. Chem. Commun. 2008, 4567-4569.

(33) (a) Yanagisawa, M.; Tashiro, K.; Yamasaki, M.; Aida, T. J. Am. Chem. Soc. 2007, 129, 11912-11913. (b) Tashiro, K.; Aida, T. Chem. Soc. Rev. 2007, 36, 189-197. (c) Sun, D.; Tham, F. S.; Reed, C. A.; Chaker, L.; Boyd, P. D. W. J. Am. Chem. Soc. 2002, 124, 6604-6612. dimers. In the latter, the redox-active units behave as their individual MPTTF components, without any detectable intramolecular interaction by CV and TLCV studies. One dimer presents a good affinity for electron-accepting $\mathrm{C}_{60}$. This finding, obtained from a basic assembly (two perpendicular electron-rich ligands linked to a metal corner), offers appealing perspectives. First, these simple systems constitute an interesting model, useful for a better understanding of the self-assembly process occurring along the construction of higher symmetry metalla-assembled systems (polygons and polyhedra). Then, the recognition properties obtained with these angular systems for $\mathrm{C}_{60}$ predict a good affinity of their higher electron-rich homologues for fullerene derivatives. The metal-assisted construction of self-assembled TTFbased polygons and polyhedra is in due course.

\section{Experimental Section}

4-(Diethoxymethyl)-5-((cyanophen-4-ylimino)methyl)-1,3-dithiol2-thione 3b. To a solution of 4-formyl-5-(diethoxymethyl)-1,3dithiole-2-thione $2(2.70 \mathrm{~g}, 10.2 \mathrm{mmol})$ in $200 \mathrm{~mL}$ of dry toluene was added an excess of 4-aminobenzonitrile (3.62 g, $30.7 \mathrm{mmol})$, and the medium was refluxed for $3 \mathrm{~h}$ with molecular sieves $(4 \AA)$ (reaction monitored by TLC $\mathrm{CH}_{2} \mathrm{Cl}_{2} /$ cyclohexane $8 / 2 \mathrm{v} / \mathrm{v}$ ). After cooling, the medium was filtered, the molecular sieves were washed with toluene, and the filtrate was concentrated under vacuum. Purification by column chromatography over silica gel $\left(\mathrm{CH}_{2} \mathrm{Cl}_{2} /\right.$ cyclohexane $8 / 2 \mathrm{v} / \mathrm{v}+1 \%$ triethylamine) afforded imine $3 \mathbf{b}(3.52 \mathrm{~g}$, $9.69 \mathrm{mmol}$ ) as a yellow solid (yield $=95 \%$ ). $\mathrm{Mp}=153-156^{\circ} \mathrm{C} .{ }^{1} \mathrm{H}$ NMR (acetone- $\left.d_{6}\right): 8.77(\mathrm{~s}, 1 \mathrm{H}), 7.85(\mathrm{~d}, 2 \mathrm{H}, J=8.7 \mathrm{~Hz}), 7.41(\mathrm{~d}$, $2 \mathrm{H}, J=8.7 \mathrm{~Hz}), 6.15(\mathrm{~s}, 1 \mathrm{H}), 3.76(\mathrm{~m}, 4 \mathrm{H}), 1.22(\mathrm{t}, 6 \mathrm{H}, J=7.2 \mathrm{~Hz})$. ${ }^{13} \mathrm{C}$ NMR (acetone- $d_{6}$ ): 212.2, 153.6, 152.8, 151.7, 139.5, 133.5, 122.1, 118.2, 110.2, 96.4, 61.9, 14.4. $\mathrm{C}_{16} \mathrm{H}_{16} \mathrm{~N}_{2} \mathrm{O}_{2} \mathrm{~S}_{3}$ : MALDI-TOF: $\mathrm{MH}^{+}$365.05. IR (KBr): 2224, 1576, $1067 \mathrm{~cm}^{-1}$.

4-(Diethoxymethyl)-5-((amino-4-pyridyl)methyl)-1,3-dithiol2-thione 5a. A solution of 4-formyl-5-(diethoxymethyl)-1,3dithiole-2-thione $2(542 \mathrm{mg}, 1.53 \mathrm{mmol})$ and iminophosphorane 4 (404 mg, $1.53 \mathrm{mmol})$ in $150 \mathrm{~mL}$ of dry toluene was refluxed under nitrogen for $12 \mathrm{~h}$ (until total consumption of starting thione 2, TLC AcOEt $/ 1 \%$ triethylamine). After cooling, toluene was removed under vacuum, and the residue was filtered over silica gel to procure a brown oil containing imine 3a and triphenylphosphine oxide. The mixture was then solubilized in $300 \mathrm{~mL}$ of dry methanol, and $\mathrm{NaBH}_{4}(75 \mathrm{mg}, 2.00$ mmol) was added at room temperature. The medium was then stirred for $15 \mathrm{~min}$, and the solvent was evaporated. The residue was dissolved in $300 \mathrm{~mL}$ of $\mathrm{CH}_{2} \mathrm{Cl}_{2}$ and washed with water. The organic layer was dried over $\mathrm{MgSO}_{4}$, filtered, and concentrated under vacuum. Purification of the residual oil by column chromatography on silica gel $\left(\mathrm{CH}_{2} \mathrm{Cl}_{2} /\right.$ methanol $9 / 1 \mathrm{v} / \mathrm{v}+$ $1 \%$ triethylamine) afforded amine $\mathbf{5 a}(366 \mathrm{mg}, 1.07 \mathrm{mmol})$ as a yellow solid $(70 \%$ yield from 2$) . \mathrm{Mp}=154-156{ }^{\circ} \mathrm{C} .{ }^{1} \mathrm{H}$ NMR (acetone- $\left.d_{6}\right): 8.15(\mathrm{dd}, 2 \mathrm{H}, J=1.6 \mathrm{~Hz}, J=4.8 \mathrm{~Hz}), 6.65(\mathrm{dd}$, $2 \mathrm{H}, J=1.6 \mathrm{~Hz}, J=4.8 \mathrm{~Hz}), 6.50(\mathrm{t}, 1 \mathrm{H}, J=6.0 \mathrm{~Hz}), 5.84(\mathrm{~s}$, $1 \mathrm{H}), 4.56(\mathrm{~d}, 2 \mathrm{H}, J=6.0 \mathrm{~Hz}), 3.72(\mathrm{~m}, 4 \mathrm{H}, J=7.2 \mathrm{~Hz}), 1.23(\mathrm{t}$, $6 \mathrm{H}, J=7.2 \mathrm{~Hz}) .{ }^{13} \mathrm{C}$ NMR (acetone- $\left.d_{6}\right): 213.2,153.7,150.7$, $145.0,140.3,108.6,97.3,62.6,41.5,15.3 . \mathrm{C}_{14} \mathrm{H}_{18} \mathrm{~N}_{2} \mathrm{O}_{2} \mathrm{~S}_{3}$ : MALDI TOF: $\mathrm{M}^{+} \bullet 342.00$. IR (KBr): $1606,1533,1505$, $1324,1044 \mathrm{~cm}^{-1}$.

4-(Diethoxymethyl)-5-((amino-4-pyridyl)methyl)-1,3-dithiol2-one 5'a. A solution of 4-formyl-5-(diethoxymethyl)-1,3dithiole-2-one $\mathbf{2}^{\prime}(1.80 \mathrm{~g}, 7.26 \mathrm{mmol})$ and iminophosphorane $4(2.65 \mathrm{~g}, 7.5 \mathrm{mmol})$ in $150 \mathrm{~mL}$ of dry toluene was refluxed for 5 $\mathrm{h}$ under nitrogen. After cooling, the solvent was removed, and the residual oil was chromatographied over silica gel (AcOEt/ $1 \%$ de triethylamine) to give a brown oil containing imine $\mathbf{3}^{\prime} \mathbf{a}$ 
and triphenylphosphine oxide. This mixture was solubilized in $250 \mathrm{~mL}$ of dry methanol, and $\mathrm{NaBH}_{4}(303 \mathrm{mg}, 8 \mathrm{mmol})$ was added at room temperature. The medium was stirred for $15 \mathrm{~min}$, and the solvent was removed under vacuum. The crude product was dissolved in $300 \mathrm{~mL}$ of $\mathrm{CH}_{2} \mathrm{Cl}_{2}$ and washed with water. The organic layer was dried over $\mathrm{MgSO}_{4}$ and filtered, and the solvent evaporated in vacuo. Purification by column chromatography over silica gel $\left(\mathrm{CH}_{2} \mathrm{Cl}_{2} /\right.$ methanol $9 / 1 \mathrm{v} / \mathrm{v}+$ $1 \%$ triethylamine) afforded amine $\mathbf{5}^{\prime} \mathbf{a}(1.55 \mathrm{~g}, 4.79 \mathrm{mmol})$ as a creamy oil (yield $66 \%$ from $2^{\prime}$ ) that is sensitive to light. ${ }^{1} \mathrm{H}$ NMR (acetone- $\left.d_{6}\right): 8.14(\mathrm{dd}, 4 \mathrm{H}, J=1.2 \mathrm{~Hz}, J=4.8 \mathrm{~Hz}), 6.65$ $(\mathrm{dd}, 4 \mathrm{H}, J=1.2 \mathrm{~Hz}, J=4.8 \mathrm{~Hz}), 6.67(\mathrm{~m}, 1 \mathrm{H}), 5.83(\mathrm{~s}, 1 \mathrm{H})$, $4.53(\mathrm{~d}, 2 \mathrm{H}, J=6.0 \mathrm{~Hz}), 3.70(\mathrm{~m}, 4 \mathrm{H}, J=7.2 \mathrm{~Hz}), 1.22(\mathrm{t}, 6 \mathrm{H}$, $J=7.2 \mathrm{~Hz}$ ). ${ }^{13} \mathrm{C} \mathrm{NMR}$ (acetone- $\left.d_{6}\right): 191.2,154.0,150.5,134.0$, 130.0, 108.6, 97.5, 62.6, 41.7, 15.3.

$\mathrm{N}$-(4-Pyridyl)-5 $\boldsymbol{H}$-1,3-dithiolo[4,5-c]pyrrole-2-thione 6a. To a solution of amine $5 \mathbf{a}(270 \mathrm{mg}, 0.79 \mathrm{mmol})$ in $250 \mathrm{~mL}$ of $\mathrm{CH}_{2} \mathrm{Cl}_{2}$ was added $20.0 \mathrm{~g}$ of dry Amberlyst A15 resin. The medium was stirred vigorously at room temperature under nitrogen (reaction monitored by TLC $\mathrm{CH}_{2} \mathrm{Cl}_{2} /$ methanol $9 / 1 \mathrm{v} / \mathrm{v}$; the reaction is finished when the medium becomes colorless). Triethylamine $(30 \mathrm{~mL})$ was added to desorb the desired compound from the resin ( $\mathrm{pH}$ must be basic). Afterward, the resin was removed by filtration and washed with $\mathrm{CH}_{2} \mathrm{Cl}_{2}$, and the filtrate was concentrated. Cold methanol $(30 \mathrm{~mL})$ was then added to the brown residue. Thione $\mathbf{6 a}$ was isolated by filtration and washed with additional cold methanol $(20 \mathrm{~mL})$. After being dried, thione $\mathbf{6 a}$ $(156 \mathrm{mg}, 0.63 \mathrm{mmol})$ was produced as a gold solid (yield = $79 \%) . \mathrm{Mp}=248-250{ }^{\circ} \mathrm{C}($ decomp $) .{ }^{1} \mathrm{H}$ NMR $\left(\mathrm{DMSO}-d_{6}\right): 8.65$ $(\mathrm{dd}, 2 \mathrm{H}, J=1.6 \mathrm{~Hz}, J=4.8 \mathrm{~Hz}), 7.92(\mathrm{~s}, 1 \mathrm{H}), 7.68(\mathrm{dd}, 2 \mathrm{H}, J=$ $1.6 \mathrm{~Hz}, J=4.8 \mathrm{~Hz}) .{ }^{13} \mathrm{C}$ NMR (DMSO- $\left.d_{6}\right): 219.8,151.5,145.0$, 125.7, 113.3, 111.1. $\mathrm{C}_{10} \mathrm{H}_{6} \mathrm{~N}_{2} \mathrm{~S}_{3}: \mathrm{M}^{+}$(calcd) 249.96931; $\mathrm{M}^{+} \cdot$ (found) 249.9687. IR (KBr): 1594, 1503, 1313, $1063 \mathrm{~cm}^{-1}$.

$\boldsymbol{N}$-(4-Pyridyl)-5 $\boldsymbol{H}$-1,3-dithiolo[4,5-c]pyrrole-2-one $\mathbf{6}^{\prime} \mathbf{a}$. To a solution of amine $\mathbf{5}^{\prime} \mathbf{a}(1.30 \mathrm{~g}, 4.01 \mathrm{mmol})$ in $130 \mathrm{~mL}$ of $\mathrm{CH}_{2} \mathrm{Cl}_{2}$ was added $55.0 \mathrm{~g}$ of Amberlyst A15 dry resin. The reaction was stirred at room temperature, and the course of the reaction followed by TLC $\left(\mathrm{CH}_{2} \mathrm{Cl}_{2} /\right.$ methanol $\left.9 / 1 \mathrm{v} / \mathrm{v}\right)$. Triethylamine $(60$ $\mathrm{mL}$ ) was slowly added. The resin was removed by filtration and washed with $\mathrm{CH}_{2} \mathrm{Cl}_{2}$. The filtrate was washed twice by water, dried over $\mathrm{MgSO}_{4}$, filtered, and concentrated under vacuum. Purification by column chromatography on silica gel $\left(\mathrm{CH}_{2} \mathrm{Cl}_{2}\right)$ methanol $9 / 1 \mathrm{v} / \mathrm{v}$ ) provided $N$-pyridyl-1,3-dithiolo[4,5-c]pyrrole-2-one $\mathbf{6}^{\prime} \mathbf{a}(374 \mathrm{mg}, 1.6 \mathrm{mmol})$ as a creamy solid (yield = $40 \%) . \mathrm{Mp}=198-199{ }^{\circ} \mathrm{C} .{ }^{1} \mathrm{H}$ NMR $\left(\mathrm{DMSO}-d_{6}\right): 8.64(\mathrm{dd}, 2 \mathrm{H}$, $J=1.6 \mathrm{~Hz}, J=4.8 \mathrm{~Hz}), 7.99(\mathrm{~s}, 2 \mathrm{H}), 7.66(\mathrm{dd}, 2 \mathrm{H}, J=1.6 \mathrm{~Hz}$, $J=4.8 \mathrm{~Hz}$ ). ${ }^{13} \mathrm{C} \mathrm{NMR}\left(\mathrm{DMSO}-d_{6}\right): 195.3,151.4,144.8,115.6$, 112.8, 112.7. $\mathrm{C}_{10} \mathrm{H}_{6} \mathrm{~N}_{2} \mathrm{OS}_{2}(\mathrm{EI}): \mathrm{M}^{+} \bullet 233.80$. IR (KBr): 1720, $1638,1594,1514,1392,1309 \mathrm{~cm}^{-1}$.

5-(p-cyanophenyl)-5H-1,3-dithiolo[4,5-c]pyrrole-2-thione $6 \mathrm{~b}$. To a solution of imine $\mathbf{3 b}(880 \mathrm{mg}, 2.41 \mathrm{mmol})$ in $150 \mathrm{~mL}$ of a $\mathrm{THF} /$ methanol mixture $(1 / 1 \mathrm{v} / \mathrm{v})$ was added $100 \mathrm{mg}$ of $\mathrm{NaBH}_{4}$ at room temperature $\left(\mathrm{TLC} \mathrm{CH} \mathrm{Cl}_{2} /\right.$ cyclohexane $8 / 2 \mathrm{v} / \mathrm{v}$ ). After 20 min stirring, the solvent was evaporated, and the residue was dissolved in $250 \mathrm{~mL}$ of $\mathrm{CH}_{2} \mathrm{Cl}_{2}$. The organic layer was washed three times with $300 \mathrm{~mL}$ of water, dried over $\mathrm{MgSO}_{4}$, and filtered. To this filtrate was added $45 \mathrm{~g}$ of Amberlyst A15 dry resin, and the medium was stirred vigorously for $20 \mathrm{~min}$ (TLC $\mathrm{CH}_{2} \mathrm{Cl}_{2} /$ cyclohexane $6 / 4 \mathrm{v} / \mathrm{v}$ ). The amberlyst resin was removed by filtration and washed with $250 \mathrm{~mL}$ of dichloromethane, and the filtrate was concentrated under vacuum. Purification by column chromatography over silica gel $\left(\mathrm{CH}_{2} \mathrm{Cl}_{2} /\right.$ cyclohexane $6 / 4 \mathrm{v} / \mathrm{v}$ ) provided thione $6 \mathbf{b}(415 \mathrm{mg}, 1.52 \mathrm{mmol})$ as a yellow solid (yield $=63 \%$ ). $\mathrm{Mp}=290{ }^{\circ} \mathrm{C}$ (decomp). ${ }^{1} \mathrm{H}$ NMR (DMSO- $\left.d_{6}\right): 8.00(\mathrm{~d}, 2 \mathrm{H}, J=8.7 \mathrm{~Hz}), 7.82(\mathrm{~d}, 2 \mathrm{H}, J=8.7 \mathrm{~Hz})$, $7.83(\mathrm{~s}, 2 \mathrm{H}) .{ }^{13} \mathrm{C}$ NMR (DMSO- $\left.d_{6}\right): 219.6,142.2,134.3,125.4$, 120.2, 118.4, 111.6, 108.9. $\mathrm{C}_{12} \mathrm{H}_{6} \mathrm{~N}_{2} \mathrm{~S}_{3}: \mathrm{M}^{+\bullet}$ (calcd) $273.9693 ; \mathrm{M}^{+\bullet}$ (found) 273.9688. IR (KBr): 2225, 1605, 1517, 1314, $1058 \mathrm{~cm}^{-1}$. 5-(p-cyanophenyl)-5 $\boldsymbol{H}$-1,3-dithiolo[4,5-c]pyrrole-2-one $\mathbf{6}^{\prime} \mathrm{b}$. To a solution of 5-p-cyanophenyl-1,3-dithiolo[4,5-c]pyrrole-2thione $\mathbf{6 b}(690 \mathrm{mg}, 2.52 \mathrm{mmol})$ in a mixture of dichloromethane $(300 \mathrm{~mL}) /$ glacial acetic acid $(12 \mathrm{~mL})$ was added in one portion $\mathrm{Hg}(\mathrm{OAc})_{2}(1.61 \mathrm{~g}, 5.04 \mathrm{mmol})\left(\mathrm{TLC} \mathrm{CH}_{2} \mathrm{Cl}_{2} /\right.$ cyclohexane $7 / 3 \mathrm{v} /$ $\mathrm{v}$ ), and the medium was stirred at room temperature for $20 \mathrm{~min}$. After filtration over hyflosupercel, the filtrate was washed with a saturated solution of sodium hydrogenocarbonate until $\mathrm{pH}=$ 7. The organic layer was dried over $\mathrm{MgSO}_{4}$ and filtered, and the solvent was evaporated in vacuo. Purification by column chromatography on silica gel $\left(\mathrm{CH}_{2} \mathrm{Cl}_{2}\right)$ procured the corresponding one $\mathbf{6}^{\prime} \mathbf{b}(350 \mathrm{mg}, 1.36 \mathrm{mmol}$ ) as a white solid (yield $=54 \%$ ). $\mathrm{Mp}=243-244{ }^{\circ} \mathrm{C} .{ }^{1} \mathrm{H}$ NMR $\left(\mathrm{CD}_{2} \mathrm{Cl}_{2}\right): 7.76(\mathrm{~d}, 2 \mathrm{H}, J=9.1$ $\mathrm{Hz}), 7.49(\mathrm{~d}, 2 \mathrm{H}, J=9.1 \mathrm{~Hz}), 7.22(\mathrm{~s}, 2 \mathrm{H}) .{ }^{13} \mathrm{C} \mathrm{NMR}\left(\mathrm{CD}_{2} \mathrm{Cl}_{2}\right)$ : $194.9,142.6,134.0,120.3,118.0,116.8,112.0,109.9 . \mathrm{C}_{12} \mathrm{H}_{6} \mathrm{~N}_{2} \mathrm{O}-$ $\mathrm{S}_{2}$ (DSQ): $\mathrm{M}^{+\bullet}$ 257.90. IR (KBr): 2225, 1701, 1636, 1604, 1517, $1389,1311 \mathrm{~cm}^{-1}$.

5-(p-Bromophenyl)-5H-1,3-dithiolo[4,5-c]pyrrole-2-thione $6 c$. To a solution of thione $2(800 \mathrm{mg}, 3.03 \mathrm{mmol})$ in $100 \mathrm{~mL}$ of dry toluene were added an excess of 4-bromoaniline $(626 \mathrm{mg}$, $3.64 \mathrm{mmol})$ and $2 \mathrm{~g}$ of molecular sieves $(4 \AA)$. The medium was refluxed for $2 \mathrm{~h}$ (reaction monitored by TLC $\mathrm{CH}_{2} \mathrm{Cl}_{2} /$ cyclohexane $1 / 1 \mathrm{v} / \mathrm{v}$ ). After cooling, the solvent was removed under vacuum. The residue was dissolved in $100 \mathrm{~mL}$ of dry methanol, and $114 \mathrm{mg}(3.01 \mathrm{mmol})$ of $\mathrm{NaBH}_{4}$ were added (reduction monitored by TLC $\mathrm{CH}_{2} \mathrm{Cl}_{2} /$ cyclohexane $1 / 1 \mathrm{v} / \mathrm{v}$ ). The medium was stirred during $1 \mathrm{~h}$ at room temperature, and then methanol was removed under vacuum. After dissolution of the residue in $200 \mathrm{~mL}$ of dichloromethane, the organic layer was washed three times with water, dried over $\mathrm{MgSO}_{4}$, and filtered. Amberlyst A15 dry resin $(30 \mathrm{~g})$ was added to the filtrate, and the mixture was stirred for $20 \mathrm{~min}\left(\mathrm{TLC} \mathrm{CH}_{2} \mathrm{Cl}_{2} /\right.$ cyclohexane $\left.1 / 1 \mathrm{v} / \mathrm{v}\right)$. The resin was then removed by filtration and washed with $250 \mathrm{~mL}$ of $\mathrm{CH}_{2} \mathrm{Cl}_{2}$, and the solvent was evaporated. Purification by column chromatography on silica gel $\left(\mathrm{CH}_{2} \mathrm{Cl}_{2} /\right.$ cyclohexane $1 / 1$ $\mathrm{v} / \mathrm{v})$ provided thione $\mathbf{6 c}(370 \mathrm{mg}, 1.13 \mathrm{mmol})$ as a yellow solid $($ yield $=37 \%) . \mathrm{Mp}=244-245^{\circ} \mathrm{C} .{ }^{1} \mathrm{H}$ NMR $\left(\mathrm{DMSO}-d_{6}\right): 7.71$ $(\mathrm{d}, 2 \mathrm{H}, J=8.7 \mathrm{~Hz}), 7.69(\mathrm{~s}, 2 \mathrm{H}), 7.57(\mathrm{~d}, 2 \mathrm{H}, J=8.7 \mathrm{~Hz}) .{ }^{13} \mathrm{C}$ NMR (DMSO- $\left.d_{6}\right): 219.9,138.9,133.2,124.9,122.5,119.7$, 112.2. $\mathrm{C}_{11} \mathrm{H}_{6} \mathrm{NBrS}_{3}: \mathrm{M}^{+\bullet}$ (calcd) $326.8846, \mathrm{M}^{+\bullet}$ (found) 326.8835 . IR (KBr): 1494, 1037, 863,821, $761 \mathrm{~cm}^{-1}$.

5-Tolyl-5H-1,3-dithiolo[4,5-c]pyrrole-2-thione $6 \mathrm{~d}$. To a solution of 4-formyl-5-(diethoxymethyl)-1,3-dithiole-2-thione $\mathbf{2}$ (100 mg, $0.38 \mathrm{mmol}$ ) in $20 \mathrm{~mL}$ of dry toluene were added an excess of $p$-toluidine $(1.00 \mathrm{~g}, 9.33 \mathrm{mmol})$ and $2 \mathrm{~g}$ of molecular sieves $(4 \AA)$. The medium was refluxed for 4 days $\left(\mathrm{TLC} \mathrm{CH} \mathrm{Cl}_{2}\right)$. After cooling, the solvent was removed. The residue was dissolved in a mixture $\mathrm{CH}_{2} \mathrm{Cl}_{2}(10 \mathrm{~mL}) / \mathrm{EtOH}(30 \mathrm{~mL})$, and $300 \mathrm{mg}$ of $\mathrm{NaBH}_{4}$ was added. The medium were then stirred for $4 \mathrm{~h}$, and solvents were removed under vacuum. The residue was dissolved in $100 \mathrm{~mL}$ of dichloromethane, washed three times with water, dried over magnesium sulfate, and filtered. To the filtrate was added $1 \mathrm{~g}$ of Amberlyst A15 dry resin, and the medium was stirred for $30 \mathrm{~min}$ ( $\mathrm{TLC} \mathrm{CH} \mathrm{Cl}_{2} /$ cyclohexane $1 / 1 \mathrm{v} / \mathrm{v}$ ). The resin was removed by filtration and washed with $150 \mathrm{~mL}$ of dichloromethane, and the filtrate was concentrated. Purification by column chromatography over silica gel $\left(\mathrm{CH}_{2} \mathrm{Cl}_{2}\right)$ afforded thione $6 \mathbf{d}(65 \mathrm{mg}, 0.25 \mathrm{mmol}$ ) as a yellow solid (yield $=66 \%$ ). $\mathrm{Mp}=196-198^{\circ} \mathrm{C} .{ }^{1} \mathrm{H}$ NMR $\left(\mathrm{DMSO}-d_{6}\right): 7.63(\mathrm{~s}, 2 \mathrm{H}), 7.46(\mathrm{~d}$, $2 \mathrm{H}, J=8.7 \mathrm{~Hz}), 7.31(\mathrm{~d}, 2 \mathrm{H}, J=8.7 \mathrm{~Hz}), 2.33(\mathrm{~s}, 3 \mathrm{H}) .{ }^{13} \mathrm{C}$ NMR (DMSO-d $): 219.8,137.4,136.8,130.7,124.2,120.5,20.8$. $\mathrm{C}_{12} \mathrm{H}_{9} \mathrm{NS}_{3}: \mathrm{M}^{+\bullet}$ (calcd) 262.9897, $\mathrm{M}^{+\bullet}$ (found) 262.9908. IR (KBr): $1511,1480,1036 \mathrm{~cm}^{-1}$.

5-(p-Iodophenyl)-5H-1,3-dithiolo[4,5-c]pyrrole-2-thione 6e. To a solution of 4-formyl-5-(diethoxymethyl)-1,3-dithiole-2-thione 2 $(1.50 \mathrm{~g}, 5.68 \mathrm{mmol})$ in $250 \mathrm{~mL}$ of dry toluene were added an excess of 4-iodoaniline ( $1.10 \mathrm{~g}, 6.00 \mathrm{mmol})$ and $4 \mathrm{~g}$ of molecular sieves (4 ̊). The medium was refluxed for $4 \mathrm{~h}$ ( $\mathrm{TLCC}_{2} \mathrm{Cl}_{2} /$ cyclohexane 
$1 / 1 \mathrm{v} / \mathrm{v})$. After cooling, the solvent was removed. The residue was dissolved in $100 \mathrm{~mL}$ of dry methanol, and $215 \mathrm{mg}$ of $\mathrm{NaBH}_{4}$ was added. The medium was then stirred for $15 \mathrm{~min}$, and the solvent was removed under vacuum. The residue was dissolved in $250 \mathrm{~mL}$ of dichloromethane, washed three times with water, dried over magnesium sulfate, and filtered. To the filtrate was added $40 \mathrm{~g}$ of Amberlyst A15 dry resin, and the medium was stirred for $20 \mathrm{~min}$ (TLC $\mathrm{CH}_{2} \mathrm{Cl}_{2} /$ cyclohexane $1 / 1 \mathrm{v} / \mathrm{v}$ ). The resin was removed by filtration and washed with $250 \mathrm{~mL}$ of dichloromethane, and the filtrate was evaporated to dryness. The solid residue was suspended in $25 \mathrm{~mL}$ of acetonitrile, isolated by filtration and washed with acetonitrile $(150 \mathrm{~mL})$ and diethyl ether $(20 \mathrm{~mL})$. Thione $\mathbf{6 e}$ was obtained $(737 \mathrm{mg}, 1.96 \mathrm{mmol})$ as a yellow crystalline solid (yield $=34 \%) . \mathrm{Mp}=249-250{ }^{\circ} \mathrm{C}$ (decomp). ${ }^{1} \mathrm{H}$ NMR (DMSO- $\left.d_{6}\right): 7.86$ (d, 2H, $\left.J=8.3 \mathrm{~Hz}\right), 7.69$ (s, 2H), 7.43 (d, 2H, $J=8.3 \mathrm{~Hz}$ ). ${ }^{13} \mathrm{C}$ NMR (DMSO- $\left.d_{6}\right): 219.9,139.3,139.0,124.9$, 122.6, 112.0, 92.3. $\mathrm{C}_{11} \mathrm{H}_{6} \mathrm{IN}_{2} \mathrm{~S}_{3}(\mathrm{DSQ}): \mathrm{M}^{+} \bullet 374.70$. IR $(\mathrm{KBr})$ : $1495,1063,756 \mathrm{~cm}^{-1}$.

$\mathrm{N}$-(4-(4-Pyridylethynyl)phenyl)-5 $\boldsymbol{H}$-1,3-dithiolo[4,5-c]pyrrole2-thione 8. To a solution of thione 6e $(108 \mathrm{mg}, 0.29 \mathrm{mmol})$ in $10 \mathrm{~mL}$ of freshly distilled THF were added 4-ethynylpyridyne 7 (39 mg, $0.38 \mathrm{mmol}), 24 \mathrm{mg}(0.13 \mathrm{mmol})$ of copper(I) iodide, and $69 \mathrm{mg}(0.005 \mathrm{mmol})$ of $\mathrm{Pd}\left(\mathrm{PPh}_{3}\right)_{4}$. The medium was degassed for $30 \mathrm{~min}$ under nitrogen, and $0.42 \mathrm{~mL}$ of triethylamine was added. Afterward, the reaction was heated at $60{ }^{\circ} \mathrm{C}$ overnight, under nitrogen. After filtration, the solvent was removed, and the residue was purified by column chromatography over silica gel $\left(\mathrm{CH}_{2} \mathrm{Cl}_{2} / \mathrm{AcOEt} 1 / 1 \mathrm{v} / \mathrm{v}\right)$. The solvent was removed to dryness, and the brown residue was dissolved in minimum of $\mathrm{CH}_{2} \mathrm{Cl}_{2}$. Petroleum ether was then added to precipitate thione 8 (46 mg, $0.13 \mathrm{mmol}$ ) as a yellow solid (yield $=45 \%$ ) which was isolated by filtration. $\mathrm{Mp}=235-238^{\circ} \mathrm{C}\left(\right.$ decomp). ${ }^{1} \mathrm{H}$ NMR (DMSO$\left.d_{6}\right): 8.64(\mathrm{~d}, 2 \mathrm{H}, J=4.3 \mathrm{~Hz}), 7.79(\mathrm{~s}, 2 \mathrm{H}), 7.76(\mathrm{~d}, 2 \mathrm{H}, J=8.7$ $\mathrm{Hz}), 7.74(\mathrm{~d}, 2 \mathrm{H}, J=8.7 \mathrm{~Hz}), 7.54(\mathrm{~d}, 2 \mathrm{H}, J=4.3 \mathrm{~Hz}) .{ }^{13} \mathrm{C}$ NMR (DMSO- $d_{6}$ ): 219.6, 150.0, 139.6, 133.5, 130.0, 125.4, 124.8, 120.1, 119.3, 111.6, 92.8, 87.5. $\mathrm{C}_{18} \mathrm{H}_{10} \mathrm{~N}_{2} \mathrm{~S}_{3}: \mathrm{M}^{+}$(calcd) 350.0006, $\mathrm{M}^{+\bullet}$ (found) 350.0006. IR (KBr): 3131, 3024, 2221, $1591,1518,1480,1310,1054 \mathrm{~cm}^{-1}$

2-[4,5-Bis(dimethylsulfanyl)-1,3-dithiol-2-ylidene]- $N$-(4-pyridyl)1,3-dithiolo[4,5-c]pyrrole 10a. A mixture of compound 6' a (270 mg, $1.15 \mathrm{mmol}$ ) and thione $9(261 \mathrm{mg}, 1.15 \mathrm{mmol})$ suspended in $12 \mathrm{~mL}$ of freshly distilled triethylphosphite was heated at $120^{\circ} \mathrm{C}$. After 30 min, an additional 1 equiv of thione 9 (261 mg, $1.15 \mathrm{mmol})$ was added, and the medium was stirred for $4 \mathrm{~h}$ at $120^{\circ} \mathrm{C}$ (precipitation of a yellow solid). After cooling, $30 \mathrm{~mL}$ of methanol were added. The solid in suspension was isolated by filtration and washed successively with methanol, dichloromethane, acetone, and diethyl ether. Compound 10a (128 mg, $0.31 \mathrm{mmol})$ was obtained as a gold yellow solid (yield $=27 \%$ ). $\mathrm{Mp}>260^{\circ} \mathrm{C} .{ }^{1} \mathrm{H}$ NMR $\left(\mathrm{DMSO}-d_{6}\right)$ : $8.56(\mathrm{dd}, 2 \mathrm{H}, J=1.6 \mathrm{~Hz}, J=4.8 \mathrm{~Hz}), 7.71(\mathrm{~s}, 2 \mathrm{H}), 7.46(\mathrm{dd}, 2 \mathrm{H}$, $J=1.6 \mathrm{~Hz}, J=4.8 \mathrm{~Hz}), 2.44(\mathrm{~s}, 6 \mathrm{H}) \cdot \mathrm{C}_{15} \mathrm{H}_{12} \mathrm{~N}_{2} \mathrm{~S}_{6}: \mathrm{M}^{+} \cdot$ (calcd) 411.9325; $\mathrm{M}^{+\bullet}$ (found) 411.9307. $\mathrm{MH}^{+}$(calcd) 412.9403; $\mathrm{MH}^{+}$ (found) 412.9405. Anal. Calcd: C, 43.66; H, 2.93; N, 6.79. Found: C, 43.95; H, 2.83; N, 6.77.

2-[4,5-Bis(dimethylsulfanyl)-1,3-dithiol-2-ylidene]- $N$-p-cyanophenyl-1,3-dithiolo[4,5-c]pyrrole 10b. A mixture of $\mathbf{6}^{\prime} \mathbf{b}(253 \mathrm{mg}$, $0.98 \mathrm{mmol})$ and thione $9(221.5 \mathrm{mg}, 0.98 \mathrm{mmol})$ suspended in 10 $\mathrm{mL}$ of freshly distilled triethylphosphite was heated at $120^{\circ} \mathrm{C}$. After $30 \mathrm{~min}$, an additional 1 equiv of thione 9 (221.5 mg, 0.98 mmol) was added and the medium was stirred for 4 additionnal hours at $120{ }^{\circ} \mathrm{C}$ (precipitation of a yellow solid). After cooling, $30 \mathrm{~mL}$ of methanol was added. The solid in suspension was then isolated by filtration and washed successively with methanol, dichloromethane, acetone and diethyl ether. Compound 10b
$(110 \mathrm{mg}, 0.25 \mathrm{mmol})$ was obtained as a yellow solid (yield $=$ $25 \%) . \mathrm{M} p>260{ }^{\circ} \mathrm{C} .{ }^{1} \mathrm{H}$ NMR (DMSO- $\left.d_{6}\right): 7.93(\mathrm{~d}, 2 \mathrm{H}, J=8.7$ $\mathrm{Hz}), 7.73(\mathrm{~d}, 2 \mathrm{H}, J=8.7 \mathrm{~Hz}), 7.65(\mathrm{~s}, 2 \mathrm{H}), 2.44(\mathrm{~s}, 6 \mathrm{H})$. $\mathrm{C}_{17} \mathrm{H}_{12} \mathrm{~N}_{2} \mathrm{~S}_{6}: \mathrm{M}^{+\bullet}$ (calcd) 435.9325; $\mathrm{M}^{+\bullet}$ (found) 435.9314. IR (KBr): 2223, 1604, 1518, 1385, 1314, 826, $749 \mathrm{~cm}^{-1}$.

Complex $\left[10 a_{2} P t d p p p\right]^{2+} \cdot 2(\text { OTf })^{-}$11. To a solution of $d p p p \operatorname{Pt}(\mathrm{OTf})_{2}(15.8 \mathrm{mg}, 17 \mu \mathrm{mol})$ in $6 \mathrm{~mL}$ of dichloromethane, was added in one portion $10 \mathrm{a}(16 \mathrm{mg}, 40 \mu \mathrm{mol})$. The medium was stirred for $12 \mathrm{~h}$. After filtration, to remove the excess of 10a which did not react, the filtrate was concentrated in a vacuum and the final complex $11(25 \mathrm{mg}, 14 \mu \mathrm{mol})$ was precipitated by addition of petroleum ether and isolated by filtration (orange solid, yield $=82 \%)$. Mp $=189-194{ }^{\circ} \mathrm{C}($ decomp $) .{ }^{1} \mathrm{H}$ NMR $\left(\mathrm{CD}_{2} \mathrm{Cl}_{2}\right): 8.87(\mathrm{~d}, 4 \mathrm{H}, J=6.0 \mathrm{~Hz}), 7.67(\mathrm{~m}, 8 \mathrm{H}), 7.36(\mathrm{~m}, 12 \mathrm{H})$, $6.87(\mathrm{~d}, 4 \mathrm{H}, J=6.0 \mathrm{~Hz}), 6.80(\mathrm{~s}, 4 \mathrm{H}), 3.23(\mathrm{~m}, 4 \mathrm{H}), 2.39(\mathrm{bs}$, $12 \mathrm{H}), 2.24(\mathrm{~m}, 2 \mathrm{H}) .{ }^{31} \mathrm{P}$ NMR $\left(\mathrm{CD}_{2} \mathrm{Cl}_{2}\right):-14.7\left(\mathrm{~J}_{\mathrm{Pt}-\mathrm{P}}=3084\right.$ $\mathrm{Hz}){ }^{19} \mathrm{~F}$ NMR $\left(\mathrm{CD}_{2} \mathrm{Cl}_{2}\right):-79 . \mathrm{C}_{58} \mathrm{H}_{50} \mathrm{~F}_{3} \mathrm{~N}_{4} \mathrm{O}_{3} \mathrm{P}_{2} \mathrm{PdS}_{13}$ : ESIFTICR (calcd) $1490.8721\left[\mathbf{1 1}-\mathrm{OTf}^{+}\right.$; (found) 1490.8789. IR (KBr): 3137, 2923, 2859, 1611, 1516, 1436, 1399, 1311, 1276, $1256,1226,1160,1031 \mathrm{~cm}^{-1}$.

Complex $\left[10 \mathrm{a}_{2} \mathrm{Pddppp}\right]^{2+} \cdot \mathbf{2}(\mathrm{OTf})^{-}$12. To a solution of $d p p p \mathrm{Pd}(\mathrm{OTf})_{2}(17.3 \mathrm{mg}, 21 \mu \mathrm{mol})$ in $6 \mathrm{~mL}$ of dichloromethane was added in one portion $10 a(20 \mathrm{mg}, 47 \mu \mathrm{mol})$. The medium was stirred for $12 \mathrm{~h}$. After filtration, to remove the excess of 10a that did not react, the filtrate was concentrated in a vacuum, and complex $12(33.4 \mathrm{mg}, 20 \mu \mathrm{mol})$ was precipitated by addition of petroleum ether and isolated by filtration (orange solid, yield = $96 \%) . \mathrm{Mp}=195-201{ }^{\circ} \mathrm{C}($ decomp $) .{ }^{1} \mathrm{H}$ NMR $\left(\mathrm{CD}_{2} \mathrm{Cl}_{2}\right): 8.83$ $(\mathrm{d}, 4 \mathrm{H}, J=6.0 \mathrm{~Hz}), 7.63(\mathrm{~m}, 8 \mathrm{H}), 7.35(\mathrm{~m}, 12 \mathrm{H}), 6.85(\mathrm{~d}, 4 \mathrm{H}$, $J=6.0 \mathrm{~Hz}), 6.80(\mathrm{~s}, 4 \mathrm{H}), 3.13(\mathrm{~m}, 4 \mathrm{H}), 2.39(\mathrm{bs}, 12 \mathrm{H}), 2.24(\mathrm{~m}$, 2H). ${ }^{31} \mathrm{P} \mathrm{NMR}\left(\mathrm{CD}_{2} \mathrm{Cl}_{2}\right): 6.83 .{ }^{19} \mathrm{~F} \mathrm{NMR}\left(\mathrm{CD}_{2} \mathrm{Cl}_{2}\right):-79$. $\mathrm{C}_{58} \mathrm{H}_{50} \mathrm{~F}_{3} \mathrm{~N}_{4} \mathrm{O}_{3} \mathrm{P}_{2} \mathrm{PdS}_{13}$ : ESI-FTICR $\left[12-\mathrm{OTf}^{+}{ }^{+}\right.$(calcd) 1579.9324; (found) 1579.9426. IR (KBr): 3137, 2929, 2859, 1614, $1518,1437,1402,1311,1257,1161,1031 \mathrm{~cm}^{-1}$.

Complex $\left[\mathbf{1 0 a}_{2} \mathbf{P t}\left(\mathrm{PEt}_{3}\right)_{2}\right]^{\mathbf{2}+} \cdot \mathbf{2}\left(\mathrm{OTf}^{-}\right) \mathbf{1 3}$. To a solution of $\mathrm{cis}^{-}$ $\left(\mathrm{PEt}_{3}\right)_{2} \mathrm{Pt}(\mathrm{OTf})_{2}(21.8 \mathrm{mg}, 30 \mu \mathrm{mol})$ in $6 \mathrm{~mL}$ of dichloromethane was added in one portion $10 \mathrm{a}(27 \mathrm{mg}, 66 \mu \mathrm{mol})$. The medium was stirred of $12 \mathrm{~h}$. After filtration, to remove the excess of 10a that did not react, the filtrate was concentrated in a vacuum, and the final complex13 (37.3 mg, $24 \mu \mathrm{mol})$ was precipitated by addition of diethyl ether and isolated by filtration (orange solid, yield $=$ $80 \%) . \mathrm{Mp}=183-188{ }^{\circ} \mathrm{C} .{ }^{1} \mathrm{H}$ NMR $\left(\mathrm{CD}_{2} \mathrm{Cl}_{2}\right): 9.10(\mathrm{~d}, 4 \mathrm{H}$, $J=5.6 \mathrm{~Hz}), 7.40(\mathrm{~d}, 4 \mathrm{H}, J=5.6 \mathrm{~Hz}), 7.04(\mathrm{~s}, 4 \mathrm{H}), 2.40(\mathrm{bs}$, $12 \mathrm{H}), 1.78(\mathrm{~m}, 12 \mathrm{H}), 1.31(\mathrm{~m}, 18 \mathrm{H}) .{ }^{31} \mathrm{P}$ NMR $\left(\mathrm{CD}_{2} \mathrm{Cl}_{2}\right):-2.5$ $\left(J_{\mathrm{Pt}-\mathrm{P}}=3103 \mathrm{~Hz}\right) .{ }^{19} \mathrm{~F} \mathrm{NMR}\left(\mathrm{CD}_{2} \mathrm{Cl}_{2}\right):-79 . \mathrm{C}_{43} \mathrm{H}_{54} \mathrm{~F}_{3} \mathrm{~N}_{4} \mathrm{O}_{3^{-}}$ $\mathrm{P}_{2} \mathrm{PtS}_{13} \mathrm{Cl}$ : ESI-FTICR $\left[13-\mathrm{OTf}^{+} \cdot \mathrm{Cl}^{\bullet}\right.$ (calcd) 1438.9366; (found) 1438.9324. IR (KBr): 3137, 1613, 1516, 1402, 1311, $1259,1159,1032 \mathrm{~cm}^{-1}$.

Acknowledgment. The authors gratefully acknowledge Dr. C. Afonso (SM3P platform, Paris) and Pr. D. Rondeau for their help during ESI-FTICR analyses and Dr. E. Levillain for his assistance in TLCV analyses. This work has been financially supported by ANR-PNANO (TTF-Based Nanomat).

Supporting Information Available: Full spectroscopic data for new compounds (UV-vis and ${ }^{1} \mathrm{H},{ }^{13} \mathrm{C},{ }^{31} \mathrm{P}$, and ${ }^{19} \mathrm{~F}$ NMR spectra), as well as cyclic voltammograms related to the compounds under study. X-ray data in CIF format for compounds $\mathbf{5 a}, \mathbf{6 a}, \mathbf{6 b}$, and $\mathbf{6 c}$. This material is available free of charge via the Internet at http://pubs.acs.org. 